\title{
Magnesium isotope fractionation during dolostone
}

weathering

$$
\begin{gathered}
\text { Ting } \mathrm{Gao}^{\mathrm{a}} \text {, Shan } \mathrm{Ke}^{\mathrm{a}^{*}} \text {, Fang-Zhen Teng }{ }^{\mathrm{b} *} \text {, Shouming Chen }{ }^{\mathrm{a}} \text {, Yongsheng } \mathrm{He}^{\mathrm{a}} \text {, } \\
\text { Shu-Guang } \mathrm{Li}^{\mathrm{a}}
\end{gathered}
$$

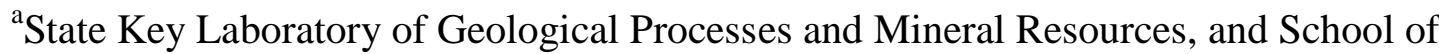
Earth Sciences and Resources, China University of Geosciences, Beijing 100083, China

${ }^{\mathrm{b}}$ Isotope Laboratory, Department of Earth and Space Sciences, University of Washington, Seattle, WA 98195, USA

\author{
Abstract: 351 words \\ Text: 5242 words \\ Table: 1 \\ Figures: 9 \\ Chemical Geology \\ (Revised version)
}

*Corresponding authors: email: keshan@cugb.edu.cn (Shan Ke), fteng@u.washingtou.edu (F.-Z. Teng)

\section{Abstract}

The element, $\mathrm{Mg}$ and $\mathrm{Sr}$ isotope ratios of a weathering profile from Hubei, China have been measured in order to document the behavior of $\mathrm{Mg}$ isotopes during dolostone weathering. The profile is developed in the joint system, and the weathering intensity increases from the least weathered dolostone towards the joint plane. According to the element and isotope ratios, the weathering profile can be divided into the weakly and intensely weathered zones. In the weakly weathered zone, $\mathrm{Mg} / \mathrm{Al}$ (atomic) ratios decrease from 4.99 to 1.75 with increasing weathering intensity, while 
$\mathrm{Ca} / \mathrm{Al}$ ratios slightly decrease from 13.70 to 9.02 . These suggest massive loss of $\mathrm{Mg}$ and simultaneous conservation of $\mathrm{Ca} . \delta^{26} \mathrm{Mg}$ values in the weakly weathered zone slightly decrease from $-1.90 \%$ to $-2.22 \%$, lighter than the corresponding protolith $(-1.90 \%)$. These element and isotope variations are likely caused by the cooccurrence of dolomite dissolution and calcite re-precipitation, suggesting that the fluids co-existing with the dolostone are saturated with respect to calcite while not saturated with respect to dolomite. By contrast, both $\mathrm{Mg} / \mathrm{Al}$ and $\mathrm{Ca} / \mathrm{Al}$ ratios of intensely weathered samples display a decreasing trend towards the joint plane, ranging from 1.62 to 0.16 and 10.24 to 2.05, respectively. The significant loss of $\mathrm{Mg}$ and $\mathrm{Ca}$ indicates the considerable dissolution of both dolomite and calcite. $\delta^{26} \mathrm{Mg}$ and ${ }^{87} \mathrm{Sr} /{ }^{86} \mathrm{Sr}$ values increase from $-2.22 \%$ to $-0.41 \%$ and from 0.71128 to 0.71368 , respectively. These observations demonstrate that the isotope compositions of the intensely weathered residues are dominantly controlled by the increasing silicate fractions after carbonate dissolution, given that silicates have considerably high ${ }^{87} \mathrm{Sr} /{ }^{86} \mathrm{Sr}$ and $\delta^{26} \mathrm{Mg}$ values relative to the carbonates. Overall, our study reveals large $\mathrm{Mg}$ isotope fractionation during dolostone weathering. The direction and extent of $\mathrm{Mg}$ isotope fractionation are mainly governed by the dissolution and re-precipitation of carbonate minerals, which are further controlled by the fluid's saturation with respect to carbonate minerals (calcite and dolomite). Therefore, cautions should be taken when using whole rock $\mathrm{Mg}$ isotope data of dolostones to trace paleoclimate change and dolostone genesis. Primary dolomite could be partially reserved in weakly weathered dolostones and step-leaching experiments may help to reveal its bearing $\mathrm{Mg}$ isotope signals.

Key words: $\mathrm{Mg}$ isotopes; dolostone weathering; dolomite dissolution; calcite re-precipitation; saturation

\section{Introduction}

Magnesium isotope composition of dolostone has been increasingly employed to constrain the evolution of seawater chemistry, paleoclimate environments and the origin of dolostone (Pokrovsky et al., 2011; Kasemann et al., 2014; Liu et al., 2014a; Geske et al., 2015a, b; Huang et al., 2015; Husson et al., 2015) due to the following geochemical characteristics. Firstly, a large fractionation between ${ }^{26} \mathrm{Mg}$ and ${ }^{24} \mathrm{Mg}$ is expected at low temperatures due to $\sim 8 \%$ relative mass difference, which has been shown between natural/synthetic inorganic/biogenic carbonates and solutions $\left(\Delta^{26} \mathrm{Mg}\right.$ $=\delta^{26} \mathrm{Mg}_{\text {carbonate }}-\delta^{26} \mathrm{Mg}_{\text {solution }}=-1 \sim-3 \%$, e.g. Higgins and Schrag, 2010; Immenhauser et al., 2010; Wombacher et al., 2011; Li et al., 2012b, 2015; Mavromatis et al., 2013; Wang et al., 2013; Saenger and Wang, 2014). Secondly, Mg is a major element in dolomite, and the potential $\mathrm{Mg}$ sources for dolostone formation, including carbonate sediments, terrestrial silicates, and seawater, have very distinct $\mathrm{Mg}$ isotope compositions (Tipper et al., 2006b; Li et al., 2012b; Huang et al., 2013; Wang et al., 2015). Thirdly, $\mathrm{Mg}$ isotope composition of the modern seawater is homogeneous (Foster et al., 2010; Ling et al., 2011), consistent with the long residence time ( 13 $\mathrm{Ma}$ ) of $\mathrm{Mg}$ in the ocean ( $\mathrm{Li}, 1982)$. Finally, the change of Mg isotope composition in 
marine carbonates on million-year scale is controlled by isotope composition of $\mathrm{Mg}$ in the oceans. The main source of $\mathrm{Mg}$ to the oceans is the weathering of carbonates and silicate rocks. These characteristics make $\mathrm{Mg}$ isotopes, combined with other stable isotopes (e.g. carbon, boron) and radiogenic strontium isotopes, potentially be an excellent tracer for chemical evolution of oceans and for paleoclimate environments, such as sea regression and transgression (Pokrovsky et al., 2011), ocean acidification event (Kasemann et al., 2014), seawater and climate evolution during post-'Snowball Earth' event (Liu et al., 2014a; Husson et al., 2015). In addition, Mg isotopes may provide a promising insight into the origin of dolostone (Geske et al., 2015a, b; Huang et al., 2015).

Nonetheless, dolostone can be altered due to recrystallization and chemical weathering (Land, 1985; Machel, 1997; Al-Aasm and Packard, 2000; Warren, 2000), which are usually accompanied by the element migration (e.g. $\mathrm{Mg}, \mathrm{Ca}$ and $\mathrm{Sr}$ ) and possible isotope fractionation (e.g. Mg, O and C; Land, 1985; Montanez and Read, 1992; Malone et al., 1994; Yoo and Lee, 1998; Fantle and Higgins, 2014). Knowledge about $\mathrm{Mg}$ isotope fractionation during diagenesis and weathering processes thus is a prerequisite to use $\mathrm{Mg}$ isotope as a proxy to reconstruct paleoclimate environments and study the origin of dolostone. Thus far, only a few studies have been carried out to constrain $\mathrm{Mg}$ isotope fractionation during diagenesis of dolostone and the results are debated. Fantle and Higgins (2014) showed that limestone diagenesis and dolomitization significantly fractionate $\mathrm{Mg}$ isotopes, implying that the diagenesis of carbonates may greatly alter their $\delta^{26} \mathrm{Mg}$ values. By contrast, Geske et al. (2012) and Azmy et al. (2013) found that diagenesis would alter the texture of the dolomite while the $\mathrm{Mg}$ isotope signals remain intact. With respect to $\mathrm{Mg}$ isotope fractionation during dolostone weathering, only one study has been carried out. Jacobson et al. (2010) investigated the fractionation mechanism during dedolomitization reactions such as dolomite dissolution, calcite precipitation and $\mathrm{Mg}$-for- $\mathrm{Na}$ ion ion-exchange, mainly based on water samples. They concluded that dolomite recrystallization and calcite precipitation did not significantly fractionate $\mathrm{Mg}$ isotopes, while the preferential uptake of ${ }^{24} \mathrm{Mg}$ during $\mathrm{Mg}$-for-Na ion-exchange was responsible for the observed isotope variation. In order to understand $\mathrm{Mg}$ isotope fractionation during dolostone weathering and its relevant controlling mechanisms, more case studies on natural weathering profiles are thus needed.

Here, we report $\mathrm{Mg}$ isotope data from a well-exposed weathering profile that developed on the Ca-dolostone from Cambrian strata in Changyang county of Hubei, China. The weathering intensity along the profile changes gradually. Thus the profile is well suitable for systematical investigation of the behaviors of $\mathrm{Mg}$ isotopes during dolostone weathering. We found large (up to $1.8 \%$ ) $\mathrm{Mg}$ isotope variation along the weathering profile and both the direction and extent of fractionation vary with the weathering intensity. The fluid's saturation with respect to carbonate minerals (calcite and dolomite) dominates the dissolution and re-precipitation of carbonates and thus controls the $\mathrm{Mg}$ isotope fractionation.

\section{Samples}


The profile studied here is from the lower Cambrian Shuijingtuo Formation in Xijiaao village, Changyang county, Hubei Province, South China ( $111^{\circ} 08^{\prime} 35.41^{\prime \prime} \mathrm{E}$, $30^{\circ} 31^{\prime} 49.82^{\prime \prime}$ N; Fig. 1A). This area is predominately covered by carbonates and shales. Carbonate rocks in this area are extensively developed with joints (Fig. 1B). The dolostone weathering profile is $\sim 17 \mathrm{~cm}$ long (the least weathered zone is defined as $0 \mathrm{~cm}$ ). The weathering degree increases gradually from the least weathered end towards joint plane with the color from black to yellow (Fig. 2). Petrographic study shows that the least weathered dolostone consists of dolomite, calcite and small amounts of silicates (dolomite + calcite $=90-95 \%$, silicates $=5-10 \%$, Fig. 3A). Alteration and carbonate recrystallization are not widely present in the least weathered dolostone. With the enhancement of weathering, the proportion of carbonate minerals decreases from $90-95 \%$ to $5-10 \%$ and that of silicate minerals increases from $5-10 \%$ to $90-95 \%$ (Fig 3. B, C, D). Besides, the grain diameter of carbonate minerals reduces and the clayzation becomes more intense on the mineral surface.

SL, DL1, DL2, DL3 and DL4 are five different deposition layers. To avoid the contamination from other deposition layers, fourteen samples (HY-PM3-3 to HY-PM3-16) were drilled from the same deposition layer (SL) (Fig. 2). To compare the geochemical composition of different deposition layers, another four samples (HY-1, HY-2, HY-3 and HY-4) were collected from four different deposition layers (DL1, DL2, DL3 and DL4) in the least weathered end (Fig. 2).

\section{Analytical methods}

The analyses of element ratios, $\mathrm{Mg}$ and $\mathrm{Sr}$ isotopes were performed at the Isotope Laboratory of the China University of Geosciences, Beijing. The procedures for sample digestion, column chemistry and instrumental analysis are described below.

\subsection{Sample digestion}

Based on the $\mathrm{Mg}$ content of samples, $1 \sim 10 \mathrm{mg}$ of rock power was weighted in Savillex screw-top beakers and was digested by using a combination of single-distilled $\mathrm{HCl}, \mathrm{HF}, \mathrm{HNO}_{3}$ and $\mathrm{HClO}_{4}$. The digestion procedures are as follows: (1) sample powders were dissolved by concentrated $\mathrm{HF}_{-} \mathrm{HNO}_{3}(3: 1, \mathrm{v} / \mathrm{v})$ as well as 3 $\sim 4$ drops of $\mathrm{HClO}_{4}$ at $140{ }^{\circ} \mathrm{C}$ for $1 \sim 2$ days, and then dried at $190{ }^{\circ} \mathrm{C}$; (2) the residues were refluxed by concentrated $\mathrm{HCl}-\mathrm{HNO}_{3}\left(3: 1\right.$, v/v) and concentrated $\mathrm{HNO}_{3}$ at $140{ }^{\circ} \mathrm{C}$ consequently; (3) Three solution splits were prepared in $3 \% \mathrm{HNO}_{3}, 1 \mathrm{~N} \mathrm{HNO}_{3}$, and $2.5 \mathrm{~N} \mathrm{HCl}$ for element ratio analysis, $\mathrm{Mg}$ and $\mathrm{Sr}$ isotope column chemistry, respectively.

\subsection{Element ratio $(\mathrm{Mg} / \mathrm{Al}, \mathrm{Ca} / \mathrm{Al}$ and $\mathrm{Mg} / \mathrm{Ca})$ analysis}

Magnesium, $\mathrm{Ca}$ and $\mathrm{Al}$ concentrations were determined and monitored by ${ }^{24} \mathrm{Mg}$, ${ }^{27} \mathrm{Al}$ and ${ }^{44} \mathrm{Ca}$ intensities on a Neptune plus MC-ICP-MS. Each measurement comprises of 10 cycles. A $400 \mathrm{ppb} \mathrm{Mg}, \mathrm{Al}$ and $\mathrm{Ca}$ mixed solution, prepared by pure 
single element standard solutions from "GSB standard", was used for calibration. The primary data are listed in Appendix A. Element ratios can be calculated by using the following formula:

$$
M / N=\left(M_{s m p} / N_{s m p}\right) \times\left(N_{s t d} / M_{s t d}\right)
$$

$M$ and $N$ refer to intensities of two monitoring isotopes; smp and std refer to sample and standard, respectively.

\subsection{Magnesium isotope analysis}

Magnesium was purified for isotope analysis through cation exchange chromatograph with Bio-Rad 200-400 mesh AG50W-X8 resin (Ke et al., 2016), by following previously established methods (Teng et al., 2007, 2010a, 2015; Yang et al., 2009; Li et al., 2010; Liu et al., 2010). The resin was cleaned by $6 \mathrm{~N} \mathrm{HCl,} 1 \mathrm{~N} \mathrm{HNO}_{3}$, $1 \mathrm{~N} \mathrm{HF}$ and Milli-Q (18.2 M $\Omega$ ) water alternatively before loading samples. Magnesium was eluted by $1 \mathrm{~N} \mathrm{HNO}_{3}$ and the $\mathrm{Mg}$ yield was between 99.5 and $99.9 \%$ based on the analyses of pure $\mathrm{Mg}$ solutions as well as reference materials (BHVO-2, BCR-2 and AGV-2). The whole procedure blank is $<10 \mathrm{ng}$, having a negligible contribution to samples. To obtain a sufficiently pure $\mathrm{Mg}$ fraction, each sample was passed through the column twice.

Magnesium isotope compositions were measured by the standard-sample bracketing method using a Neptune Plus MC-ICP-MS. A "wet" sample introduction system, equipped with a quartz spray chamber and a $50 \mathrm{ul} / \mathrm{min}$ PFA nebulizer, and low-resolution mode were adopted for $\mathrm{Mg}$ isotope analysis. Samples were introduced as $400 \mathrm{ppb}$ solutions in $3 \% \mathrm{HNO}_{3}$ and concentrations of samples and standards are matched within $\pm 10 \%$. A 400 ppb solution typically yields beam intensity of $\sim 6 \mathrm{~V}$ for ${ }^{24} \mathrm{Mg}$, with background $\mathrm{Mg}$ signals of $<10^{-4} \mathrm{~V}$. The standard-sample sequence was repeated 4 times for each sample to get a better reproducibility. Magnesium isotope ratios of samples are expressed as deviations between sample and standard DSM3 (Galy et al., 2003):

$$
\delta^{x} M g=\left[\left({ }^{x} M g /{ }^{24} M g\right)_{\text {sample }} /\left({ }^{x} M g /{ }^{24} M g\right)_{D S M 3}-1\right] \times 1000
$$

where $\mathrm{x}$ refers to mass 25 or 26 . Long term external reproducibility is $0.06 \%$ o for $\delta^{26} \mathrm{Mg}$ (2SD; Ke et al., 2016). Duplicated measurement of the seawater standard (Hawaiian seawater) yields results (average $\delta^{26} \mathrm{Mg}=-0.83 \pm 0.03 \%$, 2SD, $\mathrm{n}=2$ ) consistent with the previously reported values (Foster et al., 2010; Ling et al., 2011; Teng et al., 2015).

\subsection{Strontium isotope analysis}

Strontium was purified by cation exchange chromatography with columns filled with 2 ml Bio-Rad AG50W-X12 resin (200-400 mesh). Before separation, the resin was cleaned by $20 \mathrm{ml} 6 \mathrm{~N} \mathrm{HCl}$ and $5 \mathrm{ml}$ Milli-Q water. Samples were loaded on 0.5 $\mathrm{ml} 2.5 \mathrm{~N} \mathrm{HCl}$, followed by $1.5 \mathrm{ml} 2.5 \mathrm{~N} \mathrm{HCl}$ and $15 \mathrm{ml} 4 \mathrm{~N} \mathrm{HCl}$. Thereafter, Sr was 
collected by $7 \mathrm{ml} 4 \mathrm{~N} \mathrm{HCl}$ and $4 \mathrm{ml} 6 \mathrm{~N} \mathrm{HCl}$. Strontium isotope ratios were measured on the Neptune Plus MC-ICP-MS. Each measurement comprises $30 \mathrm{~s}$ baseline measurement at half mass positions ( 85.5 and 86.5) and 160 cycles of 4.198 second integration. ${ }^{85} \mathrm{Rb}$ and ${ }^{83} \mathrm{Kr}$ were monitored for the correction of the ${ }^{87} \mathrm{Rb}$ contribution on ${ }^{87} \mathrm{Sr}$ and ${ }^{86} \mathrm{Kr}$ on ${ }^{86} \mathrm{Sr}$. Mass bias correction was corrected against ${ }^{88} \mathrm{Sr} /{ }^{86} \mathrm{Sr}=$ 8.375209, assuming an exponential law. The measured ${ }^{87} \mathrm{Sr} /{ }^{86} \mathrm{Sr}$ of NIST SRM987 during this measurement has an average value of $0.71028 \pm 0.000031(2 \mathrm{SD}, \mathrm{n}=3)$, showing good agreement with published data (e.g. Li et al., 2012a and references therein).

\section{Results}

Element ratios $(\mathrm{Mg} / \mathrm{Al}, \mathrm{Ca} / \mathrm{Al}$ and $\mathrm{Mg} / \mathrm{Ca}), \mathrm{Mg}$ and $\mathrm{Sr}$ isotope compositions are listed in Table 1 for all the samples.

\subsection{Compositions of the different deposition layers}

The samples from the five different deposition layers (SL, DL1, DL2, DL3, DL4) represent five deposition characteristics and have different element and isotope compositions (Fig. 4). All the weathering profile samples were collected from the surface layer (SL). The least weathered dolostone from the SL has the $\mathrm{Mg} / \mathrm{Ca}, \mathrm{Mg} / \mathrm{Al}$ and $\mathrm{Ca} / \mathrm{Al}$ ratios of $0.46,5.64$ and 12.22 , respectively. $\delta^{26} \mathrm{Mg}$ ratio is $-1.90 \%$ and falls in the range of $\delta^{26} \mathrm{Mg}$ ratios of the typical dolostones (Pokrovsky et al., 2011; Azmy et al., 2013; Kasemann et al., 2014; Liu et al., 2014a; Geske et al., 2015a; Huang et al., 2015; Husson et al., 2015). ${ }^{87} \mathrm{Sr} /{ }^{86} \mathrm{Sr}$ ratio is 0.71091 , higher than that of the seawater at $520 \sim 525 \mathrm{Ma}$ (Kaufman et al., 1996; McArthur et al., 2012), reflecting the contribution of silicate fractions.

The layers DL1 and SL have similar element ratios $(\mathrm{Mg} / \mathrm{Ca}=0.41 \sim 0.46, \mathrm{Mg} / \mathrm{Al}$ $=5.64 \sim 6.00, \mathrm{Ca} / \mathrm{Al}=12.22 \sim 14.58)$ and isotope compositions $\left(\delta^{26} \mathrm{Mg}=-1.98 \% \sim\right.$ $-1.90 \%$, ${ }^{87} \mathrm{Sr} /{ }^{86} \mathrm{Sr}=0.71088 \sim 0.71091$ ) (Fig. 4). By contrast, DL2, DL3 and DL4 have rather different element ratios $(\mathrm{Mg} / \mathrm{Ca}=0.11 \sim 0.34, \mathrm{Mg} / \mathrm{Al}=2.88 \sim 8.15, \mathrm{Ca} / \mathrm{Al}$ $=12.38 \sim 25.83)$ and isotope compositions $\left(\delta^{26} \mathrm{Mg}=-1.61 \% \sim-2.08 \%{ }^{8}{ }^{87} \mathrm{Sr} /{ }^{86} \mathrm{Sr}=\right.$ $0.70971 \sim 0.71095)$. These geochemical variations among different deposition layers suggest that it is important to collect samples within the same layer when studying $\mathrm{Mg}$ isotope fractionation mechanisms during dolostone weathering. All 14 samples of the weathering profile were strictly sampled along the layer SL to avoid any disturbance from the other deposition layers. Moreover, the layer SL has similar composition to the next layer DL1, which further minimizes the possible contamination effects.

\subsection{Compositions of the weathering profile}

Several immobile elements (e.g. Al, $\mathrm{Ti}, \mathrm{Zr}$ and $\mathrm{Nd}$ ) can be used to evaluate the relative depletion or enrichment of mobile elements during chemical weathering. Similar to a previous study (Rudnick et al., 2004), Al was chosen here because it is 
one of the least mobile elements and more prone to be enriched in weathered residues. The dolostone weathering profile is divided into two different weathering zones, namely weakly weathered and intensely weathered zones, based on element ratios (Mg/Al, $\mathrm{Ca} / \mathrm{Al}$ and $\mathrm{Mg} / \mathrm{Ca}$, Fig. 5) and isotope compositions $\left(\delta^{26} \mathrm{Mg}\right.$ and ${ }^{87} \mathrm{Sr} /{ }^{86} \mathrm{Sr}$, Fig. 6).

In the weakly weathered zone, $\mathrm{Mg} / \mathrm{Al}$ and $\mathrm{Mg} / \mathrm{Ca}$ ratios are lower than the least weathered dolostone and show a decreasing trend with increasing weathering intensity, ranging from 4.99 to 1.75 and 0.44 to 0.19 , respectively (Fig. 5A, B). By contrast, $\mathrm{Ca} / \mathrm{Al}$ ratios slightly decrease from 13.70 to 9.02 (Fig. $5 \mathrm{C}$ ). $\delta^{26} \mathrm{Mg}$ values are lower than the least weathered dolostone and successively decrease from $-1.90 \%$ o to $-2.22 \%$, while ${ }^{87} \mathrm{Sr} /{ }^{86} \mathrm{Sr}$ ratios slightly increase from 0.71097 to 0.71161 (Fig. 6).

In the intensely weathered zone, $\mathrm{Mg} / \mathrm{Al}, \mathrm{Ca} / \mathrm{Al}$ and $\mathrm{Mg} / \mathrm{Ca}$ ratios all decrease as weathering intensity increases, ranging from 1.62 to $0.16,10.24$ to 2.05 and 0.16 to 0.07, respectively (Fig. 5). $\delta^{26} \mathrm{Mg}$ values and ${ }^{87} \mathrm{Sr} /{ }^{86} \mathrm{Sr}$ ratios increase significantly, varying from $-2.22 \%$ to $-0.41 \%$ and 0.71128 to 0.71368 , respectively (Fig. 6).

\section{Discussion}

Chemical weathering is a process in which primary minerals are progressively dissolved and secondary minerals are formed. Mobile elements (e.g. $\mathrm{Mg}$ and $\mathrm{Ca}$ ) during weathering are redistributed in primary minerals, secondary minerals and solutions (Nesbitt and Markovics, 1980). For example, the $\mathrm{Mg} / \mathrm{Al}$ and $\mathrm{Ca} / \mathrm{Al}$ ratios in the dolostone weathering profile here vary up to $97 \%$ and $83 \%$, respectively, suggesting that nearly all $\mathrm{Mg}$ and most of $\mathrm{Ca}$ in the most intensely weathered samples have been removed to the solution and the rest of them may be absorbed or incorporated into secondary minerals. Large $\mathrm{Mg}$ isotope fractionation had been found during weathering of igneous rocks and shales (Tipper et al., 2006a, b; Pogge von Strandmann et al., 2008; Teng et al., 2010b; Wimpenny et al., 2010; Ryu et al., 2011; Huang et al., 2012; Opfergelt et al., 2012, 2014; Pogge von Strandmann et al., 2012; Liu et al., 2014b; Ma et al., 2015). The dolostone weathering profile yields a $\delta^{26} \mathrm{Mg}$ variation up to $1.81 \%$. Particularly, those two samples near the joint plane have rather heavy $\mathrm{Mg}$ isotope compositions $(-0.41 \%$ $-0.64 \%$ ), which are close to those of igneous rocks (Teng et al., 2007, 2010a; Shen et al., 2009; Li et al., 2010; Yang et al., 2012). The large variations of element ratio and $\mathrm{Mg}$ isotope composition most likely reflect the dissolution of primary minerals and formation of secondary minerals. Below, we first discuss the behaviors of carbonate minerals and the nature of the fluids, and then reveal and model the $\mathrm{Mg}$ isotope fractionation mechanisms during dolostone weathering.

\subsection{Behaviors of carbonate minerals during dolostone weathering}

The weakly weathered zone is characterized by lower $\mathrm{Mg} / \mathrm{Al}$ ratios (1.75 to 4.99) and slight variation of $\mathrm{Ca} / \mathrm{Al}$ ratios (9.02 to 13.70) when compared to the least weathered dolostone (Fig. 5). The $\mathrm{Mg} / \mathrm{Al}$ ratios decrease with increasing weathering 
intensity, suggesting that a large amount of initial $\mathrm{Mg}$ has been gradually lost as weathering progresses. For example, the sample HY-PM3-11 has the $\mathrm{Mg} / \mathrm{Al}$ ratio of 1.75 , indicating that approximately up to $70 \%$ of $\mathrm{Mg}$ was lost. Such huge loss of $\mathrm{Mg}$ suggests substantial dissolution of dolomite since dolomite is the dominant Mg-bearing mineral in dolostone. In addition to dolomite dissolution, the less variation of $\mathrm{Ca} / \mathrm{Al}$ ratios and the significant decrease of $\mathrm{Mg} / \mathrm{Ca}$ ratios indicate that calcite re-precipitation occurs simultaneously with dolomite dissolution to compensate $\mathrm{Ca}$ and keep $\mathrm{Ca} / \mathrm{Al}$ ratios with less variation.

In contrast to the weakly weathered zone, both $\mathrm{Mg} / \mathrm{Al}$ and $\mathrm{Ca} / \mathrm{Al}$ ratios in the intensely weathered zone show a decreasing trend as weathering progresses, varying from 1.62 to 0.16 and from 10.24 to 2.05, respectively (Fig. 5). Again, dolomite dissolution is required to explain the decreasing $\mathrm{Mg} / \mathrm{Al}$ ratios but it alone cannot explain the decrease in both $\mathrm{Mg} / \mathrm{Al}$ and $\mathrm{Ca} / \mathrm{Al}$ ratios. Even dolomite in the least weathered dolostone has been completely dissolved during weathering, only approximately $46 \%$ of the bulk Ca would be lost, which cannot explain the actual $80 \%$ loss of total $\mathrm{Ca}$ calculated by $\mathrm{Ca} / \mathrm{Al}$ ratios (from 10.24 to 2.05 ) in the most intensely weathered samples. Therefore, calcite dissolution is also needed to further lower the $\mathrm{Ca} / \mathrm{Al}$ ratios in the intensely weathered zone as calcite is the only dominant Ca hosting mineral other than dolomite. Dolomite and calcite dissolution are thus concurrent in the intensely weathered zone. These conclusions are consistent with the petrographic study that the content of carbonate minerals in the intensely weathered samples is much lower than the least weathered dolostone.

The fluid-dolostone reactions involve dissolution and re-precipitation of carbonate minerals depending on the saturation state of fluids with respect to carbonate minerals. The dolomite dissolution and calcite re-precipitation as suggested in the weakly weathered zone were also observed in Chinese Loess Plateau samples (Jeong et al., 2008; Wimpenny et al., 2014a). The re-precipitation of secondary calcite is likely attributed to the saturation of fluids with respect to calcite given that large amounts of primary calcite and dolomite are dissolved causing high concentration of $\mathrm{Ca}^{2+}$ and $\mathrm{CO}_{3}{ }^{2-}$ in fluids. In addition, this cooccurrence of dolomite dissolution and calcite re-precipitation occurs in carbonate regions where gypsum or anhydrite is present (Plummer and Back, 1980; Back et al., 1983; Jacobson and Wasserburg, 2005; Jacobson et al., 2010). The irreversible dissolution of gypsum or anhydrite would make the fluid reach saturation with respect to calcite and then drive the calcite re-precipitation. The calcite re-precipitation decreases the $\mathrm{pH}$ and removes $\mathrm{CO}_{3}{ }^{2-}$ from fluids, thereby causing the dissolution of dolomite. As to the weathering profile in this study, no gypsum or anhydrite was present. Therefore, another process is needed to explain the behaviors of dolomite dissolution and calcite re-precipitation.

Jin et al. (2008) found that dolomite continuously dissolved after calcite equilibrium, because the solubility of dolomite is higher than calcite. Saturation index (SI) of the fluids with respect to calcite is defined as $\mathrm{SI}=\mathrm{Log}\left(\left[\mathrm{Ca}^{2+}\right] \times\left[\mathrm{CO}_{3}{ }^{2-}\right] / \mathrm{K}_{\text {calcite }}\right)$, where $\left[\mathrm{Ca}^{2+}\right]$ and $\left[\mathrm{CO}_{3}{ }^{2-}\right]$ are activities of $\mathrm{Ca}^{2+}$ and $\mathrm{CO}_{3}{ }^{2-}$, and $\mathrm{K}_{\text {calcite }}$ is the solubility constant of calcite. Saturation index of calcite is controlled by $\mathrm{K}_{\text {calcite }}$ and concentrations of $\mathrm{Ca}^{2+}$ and $\mathrm{CO}_{3}{ }^{2-}$. The intensely weathered zone is near the joint plane. 
Fluids, like the rain waters, are poor in $\mathrm{Ca}^{2+}, \mathrm{Mg}^{2+}$, and $\mathrm{CO}_{3}{ }^{2-}$ and thus could be undersaturated with respect to both dolomite and calcite, which could lead to substantial dissolution of dolomite and calcite in the intensely weathered zone close to the joint plane (Fig. 7). Most fluid after water-rock interaction may drain away along the joint and a small fraction of fluid infiltrates the dolostone because of the hydrostatic pressure, which would infiltrate the dolostone deeply and continue to dissolve carbonates. Massive dissolution of dolomite and calcite in the intensely weathered zone would concentrate $\mathrm{Ca}^{2+}$ and $\mathrm{CO}_{3}{ }^{2-}$ in the fluids. This could drive the infiltration fluid saturated with respect to calcite in the boundary between the weakly weathered and intensely weathered zone, whereas keep undersaturated with respect to dolomite because of the higher equilibrium constant for dolomite than that for calcite at temperatures $<30{ }^{\circ} \mathrm{C}$ (Langmuir, 1997). Thus, dolomite could continue dissolving while calcite begins to re-precipitate in the weakly weathered zone. Once calcite re-precipitation begins, $\mathrm{Ca}^{2+}$ and $\mathrm{CO}_{3}{ }^{2-}$ would be reduced, and thereby leading to a feedback of accelerating dolomite dissolution.

\subsection{Magnesium isotope fractionation during dolostone weathering}

The chemical weathering of dolostone mainly involves the dissolution of primary carbonate minerals (e.g. dolomite and calcite) and formation of secondary minerals (e.g. calcite). These processes also control the $\mathrm{Mg}$ isotope fractionation in the dolostone weathering profile. The intensely and weakly weathered zones display different fractionation directions driven by different fractionation mechanisms. Below, we discuss the behaviors of $\mathrm{Mg}$ isotopes in these two zones, respectively.

\subsubsection{The intensely weathered zone}

The least weathered dolostone is mainly composed of carbonates (90-95\%) with trace amounts of silicates (5-10\%). The intensely weathered zone is characterized by great dissolution of both dolomite and calcite due to its direct contact with externally undersaturated fluids such as rain waters. As carbonates are more reactive and soluble than silicates (Horton et al., 1999; White et al., 2005), the carbonates to silicates ratio largely decreases with increasing weathering intensity. This is supported by the much higher ${ }^{87} \mathrm{Sr} /{ }^{86} \mathrm{Sr}$ ratios $(0.71128 \sim 0.71368)$ of samples from the intensely weathered zone than the least weathered dolostone (0.71091). Since silicates have higher $\delta^{26} \mathrm{Mg}$ values than carbonates (Huang et al., 2013; Wimpenny et al., 2014a; Wang et al., 2015), $\delta^{26} \mathrm{Mg}$ values of the weathered products therefore depend on the $\mathrm{Mg}$ proportion between carbonates and silicates as well as their $\delta^{26} \mathrm{Mg}$ values. This interpretation agrees with the general increase of $\delta^{26} \mathrm{Mg}(-2.22 \%$ o $-0.41 \%$, Fig. 6) with the increasing degree of weathering. In particular, the two most intensely weathered samples (HY-PM3-15 and HY-PM3-16) have extremely heavy $\mathrm{Mg}$ isotope compositions up to $-0.41 \%$ and $-0.64 \%$ o that are close to igneous rocks (Teng et al., 2007, 2010a; Shen et al., 2009; Li et al., 2010; Yang et al., 2012). This suggests the $\mathrm{Mg}$ budget of the whole rocks is dominated by silicates and a nearly complete loss of 
carbonates, which was also found in studies of loess and paleosol (Wimpenny et al., 2014a).

\subsubsection{The weakly weathered zone}

In contrast to the intensely weathered zone, calcite re-precipitates simultaneously with dolomite dissolution in the weakly weathered zone. The positive correlation between $\delta^{26} \mathrm{Mg}$ and $\mathrm{Mg} / \mathrm{Al}$ (Fig. 8A) suggests that the heavy $\mathrm{Mg}$ isotopes are preferentially lost during chemical weathering. Four possible mechanisms could explain this fractionation of $\mathrm{Mg}$ isotopes: (1) preferential release of heavy $\mathrm{Mg}$ isotopes during dolomite dissolution; (2) preferential selection of ${ }^{24} \mathrm{Mg}$ over ${ }^{26} \mathrm{Mg}$ during Mg-for-Na ion-exchange; (3) decrease in ratio of dolomite to calcite; and (4) preferential incorporation of isotopically light $\mathrm{Mg}$ during secondary calcite precipitation.

Previously published data indicated that dolomite tends to have lighter $\mathrm{Mg}$ isotope composition than its co-existing solution (Higgins and Schrag, 2010; Fantle and Higgins, 2014; Huang et al., 2015; Li et al., 2015). However, no isotope fractionation is expected during dissolution of dolomite as shown by previous studies. River waters draining dolostones were found to have $\mathrm{Mg}$ isotope composition similar to that of dolostones (Tipper et al., 2006b). Step leaching experiments revealed that the leacheates from dolostone have constant $\delta^{26} \mathrm{Mg}$ values (Liu et al., 2014a). In this case, dolomite dissolution is not likely to be responsible for the isotope fractionation of $\mathrm{Mg}$.

$\mathrm{Mg}$ for $\mathrm{Na}$ ion-exchange process has been tentatively called to explain $\mathrm{Mg}$ isotope variation in groundwater samples as fluids preferentially remove ${ }^{24} \mathrm{Mg}$ during Mg-for-Na ion-exchange (Jacobson et al., 2010). This process, however, cannot be the main process altering $\mathrm{Mg}$ isotope composition of dolostone given that (1) silicate content in dolostone is much lower than carbonate and (2) the abundance of $\mathrm{Na}$ in dolostone is extremely limited $(\mathrm{Na} / \mathrm{Al} \leq 0.06$, see Appendix $\mathrm{A})$ and (3) the abundance of $\mathrm{Na}$ in dolostone remain unchanged as weathering intensity changes.

Instead, $\delta^{26} \mathrm{Mg}$ decline in the weakly weathered zone is likely caused by the decrease of dolomite to calcite ratio and precipitation of secondary calcite. Given that the calcite has lighter Mg isotope composition than dolomite (Galy et al., 2002; Tipper et al., 2006b), dolomite dissolution would decrease the dolomite to calcite ratio and thus lower $\delta^{26} \mathrm{Mg}$ values of whole rocks. This agrees with the positive correlations between $\mathrm{Mg} / \mathrm{Al}$ vs. $\delta^{26} \mathrm{Mg}$ as well as $\mathrm{Mg} / \mathrm{Ca}$ vs. $\delta^{26} \mathrm{Mg}$ (Fig. 8). In addition, the secondary calcite that precipitates from the infiltration fluid preferentially incorporates ${ }^{24} \mathrm{Mg}$ (Galy et al., 2002; Immenhauser et al., 2010), thereby possibly further lowering $\delta^{26} \mathrm{Mg}$ values of the dolostone.

Below, we quantitatively assess whether combined dolomite dissolution and calcite re-precipitation processes can produce the $\mathrm{Mg}$ isotope fractionation observed in the weakly weathered samples. In such a process, $\mathrm{Mg}$ isotope fractionation of weathered dolostone is determined by the input and output mass fluxes and their isotope compositions. As discussed above, the output flux of $\mathrm{Mg}$ from the weakly weathered dolostone is governed by dolomite dissolution while the input flux is due to calcite 
re-precipitation. Based on mass balance, the isotope deviation of a weathered dolostone from the least weathered dolostone $\left(\Delta_{\text {weathered-protolith }}\right)$ can be expressed by:

$$
\Delta_{\text {weathered-protolith }}=\frac{\delta_{\text {protolith }}+F_{\text {cal.r }} \times \delta_{\text {cal.r }}-F_{d o l} \times \delta_{d o l}}{1+F_{\text {cal.r }}-F_{\text {dol }}}-\delta_{\text {protolith }}
$$

where $\delta$ is the $\delta^{26} \mathrm{Mg}$ value, $F$ is the $\mathrm{Mg}$ fraction, cal. $r$ is the secondary calcite, dol is the dissolved dolomite, weathered is the weathered dolostone, and protolith is the least weathered dolostone. The $\mathrm{Mg}$ fraction $(F)$ is normalized by $\mathrm{Mg} / \mathrm{Al}$ ratio of the least weathered dolostone. Here, $\mathrm{Mg}$ isotope exchange between silicate fraction and infiltration fluid is not considered, as no evidence indicates that such isotope exchange is important given that $\mathrm{Mg}$ sink in silicates is considerably low relative to dolomites and such contribution to the bulk dolostone could not alter $\delta^{26} \mathrm{Mg}$ values of dolostone. $\delta_{\text {protolith }}$ is defined as $-1.90 \%$, a value of the least weathered dolostone in our field study. $\mathrm{Mg}$ isotope composition of secondary calcite $\left(\delta_{\text {cal.r }}\right)$ can be expressed by:

$\delta_{\text {cal.r }}=\delta_{\text {sol.r. }}+\Delta_{\text {cal.r-sol.r }}$

where sol.r refers to the infiltration fluid, and $\Delta_{\text {cal.r-sol.r }}$ refers to the fractionation factor between cal.r and sol.r. As (1) $\mathrm{Mg}$ in sol.r mainly comes from dolomite and no fractionation occurs between dolomite and the fluid, and (2) the rather small amount of $\mathrm{Mg}$ is incorporated into secondary calcite, we assume that $\delta_{\text {sol. } r}$ is similar to $\delta_{d o l}$ and keeps constant during weathering. Eq. (II) can be re-expressed by:

$\delta_{\text {cal.r. }}=\delta_{\text {dol }}+\Delta_{\text {cal. } r \text {-sol.r. }}$

In Eq. (III), $\Delta_{\text {cal. } r \text {-sol.r }}$ is adopted as $-2.6 \%$ based on the experimental calibration of temperature dependence by $\mathrm{Li}$ et al. (2012b) and local annual average temperature of $18{ }^{\circ} \mathrm{C}$ (Hu et al., 2008). Seasonal and/or annual temperature fluctuations have negligible influence on $\Delta_{\text {cal. } r \text {-sol. } r}$ due to its insensitive temperature dependence $(0.011$ $\pm 0.002 \% /{ }^{\circ} \mathrm{C}$ in $\mathrm{Li}$ et al. $2012 \mathrm{~b}$ ). Given that $\mathrm{Ca} / \mathrm{Al}$ ratios display limited variation in the weakly weathered zone, we assume that the $\mathrm{Ca}$ influx and outflux are balanced in this model, then $F_{\text {cal.r }}$ can be calculated by:

$F_{c a l . r}=\frac{F_{d o l} \times X_{M g /(M g+C a)}}{1-X_{M g /(M g+C a)}}$

where $X_{M g /(M g+C a)}$ is the proportion of $\mathrm{MgCO}_{3}$ in calcite.

The modeling results indicate that the $\mathrm{Mg}$ isotope fractionation is mainly controlled by the ratio of influx to outflux $\mathrm{Mg}$ and the isotope composition of primary dolomite (Fig. 9): (1) the higher ratio of reprecipitated $\mathrm{Mg}$ to dissolved $\mathrm{Mg}$, the larger magnitude of fractionation; (2) the heavier $\mathrm{Mg}$ isotope composition of dolomite, the easier to achieve the observed fractionation. Our data ideally fall in the modeled lines (Fig. 9), supporting the interpretation that the concurrence of dolomite dissolution and calcite re-precipitation could lead to the observed $\mathrm{Mg}$ isotope fractionation. In addition, these models appear to indicate that the secondary calcite is low $\mathrm{Mg}$ calcite $\left(X_{M g /(M g+C a)}<0.05\right)$ and the $\delta_{d o l}$ lies between $-1.75 \%$ and $-1.90 \%$.

The occurrence of both dolomite dissolution and calcite precipitation in the weakly 
weathered zone was termed as the "dedolomitization" which commonly occurs in the surface or near-surface settings (Raines and Dewers, 1997; Ronchi et al., 2004). This process is in opposite to dolomitization that is characterized by the formation of dolomite and decomposition of calcite. Fantle and Higgins (2014) found that dolomitization of limestone could lead to $1.3 \% \mathrm{Mg}$ isotope fractionation, much larger than the $0.3 \%$ variation induced by dedolomitization observed in this study. The difference of $\mathrm{Mg}$ isotope fractionation between dolomitization and dedolomitization may depend on $\mathrm{Mg}$ influx and outflux, diagenetic fractionation factors, and fluid properties. For example, dolomitization will bring much external $\mathrm{Mg}$ into the Mg-depleted limestone and lead to a large diagenetic isotope fractionation up to -2\%o, which can significantly change whole rock $\mathrm{Mg}$ isotope compositions (Fantle and Higgins, 2014). By contrast, dolomite dissolution does not appreciably fractionate $\mathrm{Mg}$ isotopes as discussed above. Additionally, samples in Fantle and Higgins (2014) were collected from an ocean drilling core and the dolomitization process occurred in an open system with a high fluid to solid mass ratio. By contrast, dedolomitization in this study took place under a surface environment with a low fluid to solid mass ratio. The fluids formed in these two different environments are probably distinct as well. The fluid during dolomitization of limestone in Fantle and Higgins (2014) is seawater-like, with $\mathrm{Mg}$ isotope composition much heavier than carbonates. However, dedolomitization fluid in this study has $\delta^{26} \mathrm{Mg}$ value similar to dolostone as discussed above.

\section{Implications}

Our study of the dolostone weathering profile demonstrates that chemical weathering can significantly fractionate $\mathrm{Mg}$ isotopes even at the scale $(\sim 17 \mathrm{~cm})$ of a hand specimen, with the direction and magnitude of isotope fractionation varying in different weathering stages. Therefore, the weathering influence has to be considered when using $\mathrm{Mg}$ isotopes of carbonates to trace paleoclimate change and the origin of dolostone.

The isotope fractionation produced in the intensely weathered zone is very large ( $1.8 \%$ ), which can easily compromise the fractionation caused by other processes. Nonetheless, intensely weathered samples could be easily identified and avoided during sampling because of their distinct petrographic features such as color, hardness, and porosity. For example, the intensely weathered samples in this study have yellow color, are soft with very high porosity because of the substantial dissolution of carbonate minerals. Although the $\mathrm{Mg}$ isotope fractionation found in the weakly weathered zone is small $(\sim 0.3 \%)$, it is still significant when compared to the variation observed in dolostone strata (e.g. 0.7\% in Kasemann et al. 2014 and 0.4\%o in Liu et al. 2014a). The weakly weathered dolostones, prevalent in dolostone strata, are difficult to identify through petrographic studies and chemical analyses because of the highly variable compositions in primary dolostone. Therefore, evaluating and minimizing the weakly weathering effects are critical for using $\mathrm{Mg}$ isotopes in dolomites to trace dolostone genesis and paleoclimate change. Our study reveals that 
the $\mathrm{Mg}$ isotope fractionation in the weakly weathered dolostones is mainly caused by dedolomitization, during which process the dissolution of the primary dolomite is unidirectional with calcite as the only secondary phase. Therefore, in the weakly weathered dolostones, primary dolomite can still be partially preserved. Then the step-leaching experiments can be used to identify the primary $\mathrm{Mg}$ isotope signature of the weathered dolostones because behaviors of dolomite, calcite and silicates are different to acid leaching, as shown in previous studies (Liu et al., 2014a; Wen et al., 2015).

\section{Conclusions}

Extreme $\mathrm{Mg}$ depletion ( 97\%) and $\mathrm{Mg}$ isotope fractionation $\left(\delta^{26} \mathrm{Mg}\right.$ up to $1.8 \%$ ) are observed in a dolostone weathering profile from Hubei, China. The weathering profile is divided into the weakly and intensely weathered zones based on the element and isotope ratios. In the weakly weathered zone, whole rock $\delta^{26} \mathrm{Mg}$ decreases from $-1.90 \%$ to $-2.22 \%$ with decreasing $\mathrm{Mg} / \mathrm{Al}$ ratios and nearly constant $\mathrm{Ca} / \mathrm{Al}$ ratios, reflecting the cooccurrence of dolomite dissolution and calcite re-precipitation, decrease in dolomite to calcite ratio, and preferential incorporation of ${ }^{24} \mathrm{Mg}$ into secondary calcite. Significant loss of both $\mathrm{Mg}$ and $\mathrm{Ca}$ is evident in the intensely weathered zone. Accordingly, $\delta^{26} \mathrm{Mg}$ increases from $-2.22 \%$ to $-0.41 \%$, and ${ }^{87} \mathrm{Sr} /{ }^{86} \mathrm{Sr}$ from 0.71128 to 0.71368 , which likely result from the increasing ratio of silicates to carbonates in the weathered residues. Our study suggests that both direction and magnitude of $\mathrm{Mg}$ isotope fractionation during dolostone weathering are controlled by dissolution and re-precipitation of carbonate minerals, as well as the saturation of carbonate minerals in the co-existing fluids. Possible weathering effect thus shall be carefully evaluated and minimized before using $\mathrm{Mg}$ isotopes of dolostone to trace dolostone genesis and paleoclimate change in the future work. Primary dolomite could be partially preserved in the weakly weathered dolostones and can be identified by step-leaching experiments.

\section{Acknowledgements}

We thank Dr. Lijuan Xu, Zijian Li, Xu-Nan Meng and Ruiying Li for help during sample analysis, and Zhengrong Wang, Lixin Jin, Jianming Zhu, Sheng-Ao Liu, Bing Shen, Kangjun Huang, Xianguo Lang, Yinghuai Lu, Pengfei Li, Chuanwei Zhu, and Ruoqi Wan for discussions. The constructive comments by Josh Wimpenny and two anonymous reviewers are greatly appreciated. This work was supported by the National Nature Scientific Foundation of China (No. 41103010, No. 41202010 and No. 41328004), the Fundamental Research Funds for the Central Universities (No. 2652014035) and the National Science Foundation (EAR 1340160).

\section{References}

Al-Aasm, I.S., Packard, J.J., 2000. Stabilization of early-formed dolomite: a tale of divergence from two Mississippian dolomites. Sedimentary Geology 131, 
97-108.

Azmy, K., Lavoie, D., Wang, Z., Brand, U., Al-Aasm, I., Jackson, S., Girard, I., 2013. Magnesium-isotope and REE compositions of Lower Ordovician carbonates from eastern Laurentia: implications for the origin of dolomites and limestones. Chemical Geology 356, 64-75.

Back, W., Hanshaw, B.B., Plummer, L.N., Rahn, P.H., Rightmire, C.T., Rubin, M., 1983. Process and rate of dedolomitization: mass transfer and ${ }^{14} \mathrm{C}$ dating in a regional carbonate aquifer. Geological Society of America Bulletin 94, 1415-1429.

Fantle, M.S., Higgins, J., 2014. The effects of diagenesis and dolomitization on Ca and $\mathrm{Mg}$ isotopes in marine platform carbonates: Implications for the geochemical cycles of $\mathrm{Ca}$ and $\mathrm{Mg}$. Geochimica et Cosmochimica Acta 142, 458-481.

Foster, G.L., Pogge von Strandmann, P.A.E., Rae, J.W.B., 2010. Boron and magnesium isotopic composition of seawater. Geochemistry, Geophysics, Geosystems 11, Q08015. doi:10.1029/2010GC003201.

Galy, A., Bar-Matthews, M., Halicz, L., O’Nions, R.K., 2002. Mg isotopic composition of carbonate: insight from speleothem formation. Earth and Planetary Science Letters 201, 105-115.

Galy, A., Yoffe, O., Janney, P.E., Williams, R.W., Cloquet, C., Alard, O., Carignan, J., 2003. Magnesium isotope heterogeneity of the isotopic standard SRM980 and new reference materials for magnesium-isotope-ratio measurements. Journal of Analytical Atomic Spectrometry 18, 1352-1356.

Geske, A., Zorlu, J., Richter, D.K., Buhl, D., Niedermayr, A., Immenhauser, A., 2012. Impact of diagenesis and low grade metamorphosis on isotope $\left(\delta^{26} \mathrm{Mg}, \delta^{13} \mathrm{C}\right.$, $\delta^{18} \mathrm{O}$ and $\left.{ }^{87} \mathrm{Sr} /{ }^{86} \mathrm{Sr}\right)$ and elemental $(\mathrm{Ca}, \mathrm{Mg}, \mathrm{Mn}, \mathrm{Fe}$ and $\mathrm{Sr}$ ) signatures of Triassic sabkha dolomites. Chemical Geology 332, 45-64.

Geske, A., Goldstein, R.H., Mavromatis, V., Richter, D.K., Buhl, D., Kluge, T., Immenhauser, A., 2015a. The magnesium isotope $\left(\delta^{26} \mathrm{Mg}\right)$ signature of dolomites. Geochimica et Cosmochimica Acta 149, 131-151.

Geske, A., Lokier, S., Dietzel, M., Richter, D.K., Buhl, D., Immenhauser, A., 2015b. Magnesium isotope composition of sabkha porewater and related (Sub-) Recent stoichiometric dolomites, Abu Dhabi (UAE). Chemical Geology 393, 112-124.

Higgins, J., Schrag, D., 2010. Constraining magnesium cycling in marine sediments using magnesium isotopes. Geochimica et Cosmochimica Acta 74, 5039-5053.

Horton, T.W., Chamberlain, C.P., Fantle, M., Blum, J.D., 1999. Chemical weathering and lithologic controls of water chemistry in a high-elevation river system: Clark's Fork of the Yellowstone River, Wyoming and Montana. Water Resources Research 35, 1643-1655.

Hu, C., Henderson, G., Huang, J., Chen, Z., Johnson, K., 2008. Report of a three-year monitoring programme at Heshang Cave, Central China. International Journal of Speleology 37, 143-151.

Huang, K.-J., Teng, F.-Z., Wei, G.-J., Ma, J.-L., Bao, Z.-Y., 2012. Adsorption- and 
desorption-controlled magnesium isotope fractionation during extreme weathering of basalt in Hainan Island, China. Earth and Planetary Science Letters 359, 73-83.

Huang, K.-J., Teng, F.-Z., Elsenouy, A., Li, W.-Y., Bao, Z.-Y., 2013. Magnesium isotopic variations in loess: Origins and implications. Earth and Planetary Science Letters 374, 60-70.

Huang, K.-J., Shen, B., Lang, X.G., Tang, W.B., Peng, Y., Ke, S., Li, F.B., 2015. Magnesium isotopic compositions of the Mesoproterozoic dolostones: Implications for $\mathrm{Mg}$ isotopic systematics of marine carbonate. Geochimica et Cosmochimica Acta 164, 333-351.

Husson, J.M., Higgins, J.A., Maloof, A.C., Schoene, B., 2015. Ca and Mg isotope constraints on the origin of Earth's deepest $\delta^{13} \mathrm{C}$ excursion. Geochimica et Cosmochimica Acta 160, 243-266.

Immenhauser, A., Buhl, D., Richter, D., Niedermayr, A., Riechelmann, D., Dietzel, M., Schulte, U., 2010. Magnesium-isotope fractionation during low-Mg calcite precipitation in a limestone cave-Field study and experiments. Geochimica et Cosmochimica Acta 74, 4346-4364.

Jacobson, A., Wasserburg, G., 2005. Anhydrite and the Sr isotope evolution of groundwater in a carbonate aquifer. Chemical Geology 214, 331-350.

Jacobson, A.D., Zhang, Z., Lundstrom, C., Huang, F., 2010. Behavior of Mg isotopes during dedolomitization in the Madison Aquifer, South Dakota. Earth and Planetary Science Letters 297, 446-452.

Jeong G.Y., Hillier S., Kemp R.A., 2008. Quantitative bulk and single-particle mineralogy of a thick Chinese loess-paleosol section: implications for loess provenance and weathering. Quaternary Science Reviews 27, 1271-1287.

Jiang, G., Wang, X., Shi, X., Xiao, S., Zhang, S., Dong, J., 2012. The origin of decoupled carbonate and organic carbon isotope signatures in the early Cambrian (ca. 542-520Ma) Yangtze platform. Earth and Planetary Science Letters 317, 96-110.

Jin, L., Williams, E.L., Szramek, K.J., Walter, L.M., \& Hamilton, S.K., 2008. Silicate and carbonate mineral weathering in soil profiles developed on Pleistocene glacial drift (Michigan, USA): Mass balances based on soil water geochemistry. Geochimica et Cosmochimica Acta 72, 1027-1042.

Kasemann, S.A., Pogge von Strandmann, P.A.E., Prave, A.R., Fallick, A.E., Elliott, T., Hoffmann, K.H., 2014. Continental weathering following a Cryogenian glaciation: Evidence from calcium and magnesium isotopes. Earth and Planetary Science Letters 396, 66-77.

Kaufman, A.J., Knoll, A.H., Semikhatov, M.A., Grotzinger, J.P., Jacobsen, S.B., Adams, W., 1996. Integrated chronostratigraphy of Proterozoic-Cambrian boundary beds in the western Anabar region, northern Siberia. Geological Magazine 133, 509-533.

Ke, S., Teng, F.-Z., Li, S., Gao, T., Liu, S.-A., He, Y., Mo, X., 2016. Mg, Sr, and O isotope geochemistry of syenites from northwest Xinjiang, China: Tracing carbonate recycling during Tethyan oceanic subduction. Chemical Geology 37, 
109-119..

Land, L.S., 1985. The origin of massive dolomite. Journal of Geological Education 33, 112-125.

Langmuir, D., 1997. Aqueous Environmental Geochemistry. Prentice Hall, Upper Saddle River, NY, 600 p.

Li, C.F., Li, X.H., Li, Q.L., Guo, J.H., Li, X.H., Yang, Y.H., 2012a. Rapid and precise determination of $\mathrm{Sr}$ and $\mathrm{Nd}$ isotopic ratios in geological samples from the same filament loading by thermal ionization mass spectrometry employing a single-step separation scheme. Analytica Chimica Acta 727, 54-60.

Li, W., Chakraborty, S., Beard, B.L., Romanek, C.S., Johnson, C.M., 2012 b. Magnesium isotope fractionation during precipitation of inorganic calcite under laboratory conditions. Earth and Planetary Science Letters 333, 304-316.

Li, W., Beard, B.L., Li, C., Xu, H., Johnson, C.M., 2015. Experimental calibration of $\mathrm{Mg}$ isotope fractionation between dolomite and aqueous solution and its geological implications. Geochimica et Cosmochimica Acta 157, 164-181.

Li, W.-Y., Teng, F.-Z., Ke, S., Rudnick, R.L., Gao, S., Wu, F.Y., Chappell, B.W., 2010. Heterogeneous magnesium isotopic composition of the upper continental crust. Geochimica et Cosmochimica Acta 74, 6867-6884.

Li Y.H., 1982. A brief discussion on the mean oceanic residence time of elements. Geochimica et Cosmochimica Acta 46, 2671-2675.

Ling, M.X., Sedaghatpour, F., Teng, F.-Z., Hays, P.D., Strauss, J., Sun, W., 2011. Homogeneous magnesium isotopic composition of seawater: an excellent geostandard for $\mathrm{Mg}$ isotope analysis. Rapid Communications in Mass Spectrometry 25, 2828-2836.

Liu, C., Wang, Z., Raub, T.D., Macdonald, F.A., Evans, D.A., 2014a. Neoproterozoic cap-dolostone deposition in stratified glacial meltwater plume. Earth and Planetary Science Letters 404, 22-32.

Liu, S.-A., Teng, F.-Z., He, Y., Ke, S., Li, S.-G., 2010. Investigation of magnesium isotope fractionation during granite differentiation: Implication for $\mathrm{Mg}$ isotopic composition of the continental crust. Earth and Planetary Science Letters 297, 646-654.

Liu, X.-M., Teng, F.-Z., Rudnick, R.L., McDonough, W.F., Cummings, M.L., 2014b. Massive magnesium depletion and isotope fractionation in weathered basalts. Geochimica et Cosmochimica Acta 135, 336-349.

Ma, L., Teng, F.-Z., Jin, L., Ke, S., Yang, W., Gu, H.O., Brantley, S.L., 2015. Magnesium isotope fractionation during shale weathering in the Shale Hills Critical Zone Observatory: Accumulation of light $\mathrm{Mg}$ isotopes in soils by clay mineral transformation. Chemical Geology 397, 37-50.

Machel, H.G., 1997. Recrystallization versus neomorphism, and the concept of 'significant recrystallization' in dolomite research. Sedimentary Geology 113, 161-168.

Malone, M.J., Baker, P.A., Burns, S.J., 1994. Recrystallization of dolomite: evidence from the Monterey Formation (Miocene), California. Sedimentology 41, 
1223-1239.

Mavromatis, V., Gautier, Q., Bosc, O., Schott, J., 2013. Kinetics of Mg partition and $\mathrm{Mg}$ stable isotope fractionation during its incorporation in calcite. Geochimica et Cosmochimica Acta 114, 188-203.

McArthur, J.M., Howarth, R.J., Shields, G.A., 2012. Strontium isotope stratigraphy. In: Gradstein, F.M., Ogg, J.G., Schmitz, M.D. Ogg, G.M. (Eds), The Geologic Time Scale. Elsevier, pp. 127-144.

Montanez, I.P., Read, J.F., 1992. Fluid-rock interaction history during stabilization of early dolomites, upper Knox Group (Lower Ordovician), US Appalachians. Journal of Sedimentary Research 62, 753-778.

Nesbitt, H.W., Markovics, G., 1980. Chemical processes affecting alkalis and alkaline earths during continental weathering. Geochimica et Cosmochimica Acta 44, 1659-1666.

Opfergelt, S., Georg, R.B., Delvaux, B., Cabidoche, Y.M., Burton, K.W., Halliday, A.N., 2012. Mechanisms of magnesium isotope fractionation in volcanic soil weathering sequences, Guadeloupe. Earth and Planetary Science Letters 341, 176-185.

Opfergelt, S., Burton, K.W., Georg, R.B., West, A.J., Guicharnaud, R.A., Sigfusson, B., Halliday, A.N., 2014. Magnesium retention on the soil exchange complex controlling $\mathrm{Mg}$ isotope variations in soils, soil solutions and vegetation in volcanic soils, Iceland. Geochimica et Cosmochimica Acta 125, 110-130.

Plummer, L.N., Back, W., 1980. The mass balance approach: application to interpreting the chemical evolution of hydrologic systems. American Journal of Science 280, 130-142.

Pogge von Strandmann, P.A.E., Burton, K.W., James, R.H., van Calsteren, P., Gislason, S.R., Sigfússon, B., 2008. The influence of weathering processes on riverine magnesium isotopes in a basaltic terrain. Earth and Planetary Science Letters 276, 187-197.

Pogge von Strandmann, P.A.E., Opfergelt, S., Lai, Y.J., Sigfússon, B., Gislason, S.R., Burton, K.W., 2012. Lithium, magnesium and silicon isotope behaviour accompanying weathering in a basaltic soil and pore water profile in Iceland. Earth and Planetary Science Letters 339, 11-23.

Pokrovsky, B.G., Mavromatis, V., Pokrovsky, O.S., 2011. Co-variation of Mg and C isotopes in late Precambrian carbonates of the Siberian Platform: A new tool for tracing the change in weathering regime? Chemical Geology 290, 67-74.

Raines M.A., Dewers T.A., 1997. Dedolomitization as a driving mechanism for karst generation in Permian Blaine Formation, southwestern Oklahoma, USA. Carbonates and Evaporites 12, 24-31.

Ronchi P., Jadoul F., Savino R., 2004. Quaternary dedolomitization along fracture systems in a late triassic dolomitized platform (Western Southern Alps, Italy). Carbonates and Evaporites 19, 51-66.

Rudnick, R.L., Tomascak, P.B., Njo, H.B., Gardner, L.R., 2004. Extreme lithium isotopic fractionation during continental weathering revealed in saprolites from South Carolina. Chemical Geology 212, 45-57. 
Ryu, J.-S., Jacobson, A.D., Holmden, C., Lundstrom, C., Zhang, Z., 2011. The major ion, $\delta^{44 / 40} \mathrm{Ca}, \delta^{44 / 42} \mathrm{Ca}$, and $\delta^{26 / 24} \mathrm{Mg}$ geochemistry of granite weathering at $\mathrm{pH}=1$ and $\mathrm{T}=25^{\circ} \mathrm{C}$ : power-law processes and the relative reactivity of minerals. Geochimica et Cosmochimica Acta 75, 6004-6026.

Saenger, C., Wang, Z., 2014. Magnesium isotope fractionation in biogenic and abiogenic carbonates: implications for paleoenvironmental proxies. Quaternary Science Reviews 90, 1-21.

Schauble, E.A., 2011. First-principles estimates of equilibrium magnesium isotope fractionation in silicate, oxide, carbonate and hexaaquamagnesium (2+) crystals. Geochimica et Cosmochimica Acta 75, 844-869.

Shen, B., Jacobsen, B., Lee, C.-T.A., Yin, Q.-Z., Morton, D.M., 2009. The Mg isotopic systematics of granitoids in continental arcs and implications for the role of chemical weathering in crust formation. Proceedings of the National Academy of Sciences 106, 20652-20657.

Teng, F.-Z., Wadhwa, M., Helz, R.T., 2007. Investigation of magnesium isotope fractionation during basalt differentiation: Implications for a chondritic composition of the terrestrial mantle. Earth and Planetary Science Letters 261, 84-92.

Teng, F.-Z., Li, W.-Y., Ke, S., Marty, B., Dauphas, N., Huang, S., Pourmand, A., 2010a. Magnesium isotopic composition of the Earth and chondrites. Geochimica et Cosmochimica Acta 74, 4150-4166.

Teng, F.-Z., Li, W.-Y., Rudnick, R.L., Gardner, L.R., 2010b. Contrasting lithium and magnesium isotope fractionation during continental weathering. Earth and Planetary Science Letters 300, 63-71.

Teng, F.-Z., Li, W.-Y., Ke, S., Yang, W., Liu, S.-A., Sedaghatpour, F., Xiao, Y., 2015. Magnesium Isotopic Compositions of International Geological Reference Materials. Geostandards and Geoanalytical Research 39, 329-339.

Tipper, E., Galy, A., Bickle, M., 2006a. Riverine evidence for a fractionated reservoir of $\mathrm{Ca}$ and $\mathrm{Mg}$ on the continents: Implications for the oceanic $\mathrm{Ca}$ cycle. Earth and Planetary Science Letters 247, 267-279.

Tipper, E., Galy, A., Gaillardet, J., Bickle, M.J., Elderfield, H., Carder, E.A., 2006b. The magnesium isotope budget of the modern ocean: Constraints from riverine magnesium isotope ratios. Earth and Planetary Science Letters 250, 241-253.

Wang, S.-J., Teng, F.-Z., Rudnick, R.L., Li, S.-G., 2015. The behavior of magnesium isotopes in low-grade metamorphosed mudrocks. Geochimica et Cosmochimica Acta 165, 435-448.

Wang, Z., Hu, P., Gaetani, G., Liu, C., Saenger, C., Cohen, A., Hart, S., 2013. Experimental calibration of $\mathrm{Mg}$ isotope fractionation between aragonite and seawater. Geochimica et Cosmochimica Acta 102, 113-123.

Warren, J., 2000. Dolomite: occurrence, evolution and economically important associations. Earth-Science Reviews 52, 1-81.

Wen B., Evans D.A.D., Li Y.X., Wang, Z., Liu, C., 2015. Newly discovered Neoproterozoic diamictite and cap carbonate (DCC) couplet in Tarim Craton, NW China: Stratigraphy, geochemistry, and paleoenvironment. Precambrian 
Research 271, 278-294.

White, A.F., Schulz, M.S., Lowenstern, J.B., Vivit, D.V., Bullen, T.D., 2005. The ubiquitous nature of accessory calcite in granitoid rocks: implications for weathering, solute evolution, and petrogenesis. Geochimica et Cosmochimica Acta 69, 1455-1471.

Wimpenny, J., Gíslason, S.R., James, R.H., Gannoun, A., Pogge von Strandmann, P.A.E., Burton, K.W., 2010. The behaviour of $\mathrm{Li}$ and $\mathrm{Mg}$ isotopes during primary phase dissolution and secondary mineral formation in basalt. Geochimica et Cosmochimica Acta 74, 5259-5279.

Wimpenny, J., Yin, Q.-Z., Tollstrup, D., Xie, L.-W., Sun, J., 2014a. Using Mg isotope ratios to trace Cenozoic weathering changes: A case study from the Chinese Loess Plateau. Chemical Geology 376, 31-43.

Wimpenny, J., Colla, C.A., Yin, Q.-Z., Rustad, J.R., Casey, W.H., 2014b. Investigating the behaviour of $\mathrm{Mg}$ isotopes during the formation of clay minerals. Geochimica et Cosmochimica Acta 128, 178-194.

Wombacher, F., Eisenhauer, A., Böhm, F., Gussone, N., Regenberg, M., Dullo, W.C., Rüggeberg, A., 2011. Magnesium stable isotope fractionation in marine biogenic calcite and aragonite. Geochimica et Cosmochimica Acta 75, 5797-5818.

Yang, W., Teng, F.-Z., Zhang, H.-F., 2009. Chondritic magnesium isotopic composition of the terrestrial mantle: a case study of peridotite xenoliths from the North China craton. Earth and Planetary Science Letters 288, 475-482.

Yang, W., Teng, F.-Z., Zhang, H.-F., Li, S.-G., 2012. Magnesium isotopic systematics of continental basalts from the North China craton: Implications for tracing subducted carbonate in the mantle. Chemical Geology 328, 185-194.

Yoo, C.M., Lee, Y.I., 1998. Origin and modification of early dolomites in cyclic shallow platform carbonates, Yeongheung Formation (Middle Ordovician), Korea. Sedimentary Geology 118, 141-157. 
805

806 807

Table 1: Element ratios and isotope compositions of standards and weathered dolostone samples from Hubei, China.

\begin{tabular}{|c|c|c|c|c|c|c|c|c|c|c|}
\hline $\begin{array}{c}\text { Layer } \\
\text { ID }\end{array}$ & Sample ID & $\begin{array}{l}\text { Distanc } \\
\mathrm{e}(\mathrm{cm})\end{array}$ & $\mathrm{Mg} / \mathrm{Ca}$ & $\mathrm{Mg} / \mathrm{Al}$ & $\mathrm{Ca} / \mathrm{Al}$ & ${ }^{87} \mathrm{Sr} /{ }^{86} \mathrm{Sr}$ & $\begin{array}{c}\delta^{25} \mathrm{Mg} \\
(\%) \\
\end{array}$ & $2 \mathrm{SD}$ & $\begin{array}{c}\delta^{26} \mathrm{Mg} \\
(\%) \\
\end{array}$ & $2 \mathrm{SD}$ \\
\hline \multirow{14}{*}{ SL } & HY-PM3-3* & 0.0 & 0.46 & 5.64 & 12.22 & 0.71091 & -1.02 & 0.04 & -1.90 & 0.04 \\
\hline & HY-PM3-4 & 2.0 & 0.44 & 4.47 & 10.11 & 0.71118 & -0.99 & 0.03 & -1.90 & 0.03 \\
\hline & HY-PM3-5 & 4.0 & 0.40 & 4.99 & 12.54 & 0.71097 & -0.98 & 0.08 & -1.92 & 0.08 \\
\hline & HY-PM3-6 & 7.7 & 0.24 & 3.02 & 12.42 & 0.71161 & -1.04 & 0.05 & -2.02 & 0.05 \\
\hline & HY-PM3-7 & 9.4 & 0.32 & 3.41 & 10.77 & 0.71152 & -1.02 & 0.05 & -1.99 & 0.05 \\
\hline & HY-PM3-8 & 10.0 & 0.21 & 2.86 & 13.70 & 0.71130 & -1.10 & 0.08 & -2.11 & 0.08 \\
\hline & HY-PM3-9 & 10.7 & 0.21 & 2.78 & 12.98 & 0.71129 & -1.07 & 0.04 & -2.06 & 0.04 \\
\hline & HY-PM3-10 & 11.7 & 0.21 & 2.34 & 11.13 & 0.71125 & -1.12 & 0.06 & -2.17 & 0.06 \\
\hline & HY-PM3-11 & 12.7 & 0.19 & 1.75 & 9.02 & 0.71137 & -1.15 & 0.06 & -2.22 & 0.06 \\
\hline & HY-PM3-12 & 13.7 & 0.16 & 1.62 & 10.24 & 0.71128 & -1.14 & 0.06 & -2.22 & 0.06 \\
\hline & HY-PM3-13 & 14.7 & 0.13 & 1.04 & 8.06 & 0.71143 & -1.12 & 0.01 & -2.17 & 0.03 \\
\hline & HY-PM3-14 & 15.7 & 0.12 & 0.28 & 2.23 & 0.71353 & -0.73 & 0.01 & -1.41 & 0.01 \\
\hline & HY-PM3-15 & 16.2 & 0.07 & 0.16 & 2.22 & 0.71249 & -0.21 & 0.03 & -0.41 & 0.01 \\
\hline & HY-PM3-16 & 16.7 & 0.09 & 0.17 & 2.05 & 0.71368 & -0.34 & 0.07 & -0.64 & 0.03 \\
\hline DL1 & HY-1 & I & 0.41 & 6.00 & 14.58 & 0.71088 & -1.01 & 0.04 & -1.98 & 0.05 \\
\hline DL2 & HY-2 & I & 0.11 & 2.88 & 25.83 & 0.70971 & -1.06 & 0.09 & -2.08 & 0.03 \\
\hline DL3 & HY-3 & I & 0.34 & 8.15 & 23.88 & 0.71018 & -0.83 & 0.03 & -1.61 & 0.10 \\
\hline DL4 & HY-4 & I & 0.30 & 3.77 & 12.38 & 0.71095 & -1.00 & 0.09 & -1.95 & 0.07 \\
\hline \multirow{7}{*}{ l } & Seawater & I & I & I & I & I & -0.43 & 0.07 & -0.84 & 0.07 \\
\hline & Seawater & I & I & I & I & I & -0.40 & 0.07 & -0.82 & 0.06 \\
\hline & Average & I & I & I & I & I & -0.42 & 0.04 & -0.83 & 0.03 \\
\hline & SRM987 & l & I & I & I & 0.71029 & I & I & l & I \\
\hline & SRM987 & I & I & I & I & 0.71028 & I & I & I & I \\
\hline & SRM987 & I & I & I & I & 0.71026 & I & I & I & I \\
\hline & Average & I & I & I & I & 0.71028 & I & I & I & 1 \\
\hline
\end{tabular}

808

809

810

811

812

813

814

815

816

817

818

819

820

821

822

823

$\delta^{\mathrm{x}} \mathrm{Mg}=\left[\left({ }^{\mathrm{x}} \mathrm{Mg} /{ }^{24} \mathrm{Mg}\right)_{\text {sample }} /\left({ }^{\mathrm{x}} \mathrm{Mg} /{ }^{24} \mathrm{Mg}\right)_{\mathrm{DSM}}-1\right] \times 1000$, where $\mathrm{x}=25$ or 26 and DSM3 is $\mathrm{Mg}$ solution made from pure $\mathrm{Mg}$ metal (Galy et al., 2003). 2SD = 2 times the standard deviation of population analyzed. "*” represents the least weathered dolostone. " " represents the inexistence or no measurements. 


\section{Figure Captions}

Figure 1: (A) Geological map of the study area in Hubei Province, South China (modified after Jiang et al., 2012). The star represents the study area. (B) The photo of weathering profile in the field. The arrow represents the sample location.

Figure 2: Photograph of the specimen (A) and sketch (B) of the dolostone weathering profile in Hubei Province of South China. SL represents the sampling layer. 14 samples were successively taken from the least weathered end to the most weathered end in this layer. DL1, DL2, DL3 and DL4 represent different layers paralleling to the SL layer, and one sample was taken from each layer in the least weathered end.

Figure 3: Photomicrographs of the samples in different weathering zones. (A) the least weathered dolostone; (B) and (C) samples in the weakly weathered zone; (D) a sample in the intensely weathered zone. The relative proportions of each section are described as follows: $(\mathrm{A})$ carbonates $=90-95 \%$, silicates $=5-10 \%$; (B) carbonates $=$ $80-85 \%$, silicates $=15-20 \%$; $(\mathrm{C})$ carbonates $=75-80 \%$, silicates $=20-25 \%$; (D) carbonates $=5-10 \%$, silicates $=90-95 \%$.

Figure 4: The element ratios $(\mathrm{Mg} / \mathrm{Ca}, \mathrm{Mg} / \mathrm{Al}, \mathrm{Ca} / \mathrm{Al})$ and isotope compositions $\left({ }^{87} \mathrm{Sr} /{ }^{86} \mathrm{Sr}, \delta^{26} \mathrm{Mg}\right)$ of different deposition layers (SL, DL1, DL2, DL3 and DL4). Data are reported in Table 1.

Figure 5: $\mathrm{Mg} / \mathrm{Al}(\mathrm{A}), \mathrm{Ca} / \mathrm{Al}(\mathrm{B}), \mathrm{Mg} / \mathrm{Ca}(\mathrm{C})$ as a function of distance in the dolostone weathering profile. The star represents the least weathered dolostone. Error bars represent 2SD uncertainties. Data are reported in Table 1.

Figure 6: $\delta^{26} \mathrm{Mg}$ (A) and ${ }^{87} \mathrm{Sr} /{ }^{86} \mathrm{Sr}$ (B) as a function of distance in the dolostone weathering profile. The star represents the least weathered dolostone. Error bars represent 2SD uncertainties. Data are reported in Table 1.

Figure 7: Schematic diagram of carbonate mineral behaviors and fluid's properties along the dolostone weathering profile. In the intensely weathered zone, the fluids from the joint are undersaturated with respect to both dolomite and calcite. In the weakly weathered zone, the fluids become saturated with respect to calcite but undersaturated with respect to dolomite after interaction with dolomites and calcites in the intensely weathered zone.

Figure 8: $\mathrm{Mg} / \mathrm{Al}(\mathrm{A})$ and $\mathrm{Mg} / \mathrm{Ca}(\mathrm{B})$ as a function of $\delta^{26} \mathrm{Mg}$. The star represents the least weathered dolostone. Error bars represent 2SD uncertainties. Data are reported in Table 1.

Figure 9: $\sum F_{i}$ vs. $\Delta_{\text {weathered-protolith }}$ of the weakly weathered zone in dolostone weathering profile. $\sum F_{i}$ is the sum of $\mathrm{Mg}$ fraction: $\sum F_{i}=1+F_{\text {cal.r }}-F_{\text {dol }}$. $\Delta_{\text {weathered-protolith }}=\delta_{\text {weathered }}-\delta_{\text {protolith }}$, weathered and protolith represent the weathered and the least weathered dolostone, respectively. (A) $\delta_{\mathrm{dol}}=-1.90 \%$; (B) $\delta_{\mathrm{dol}}=-1.80 \%$; (C) $\delta_{\text {dol }}=-1.75 \%$. 


\section{Gao et al. Figure 1}

\section{(A)}

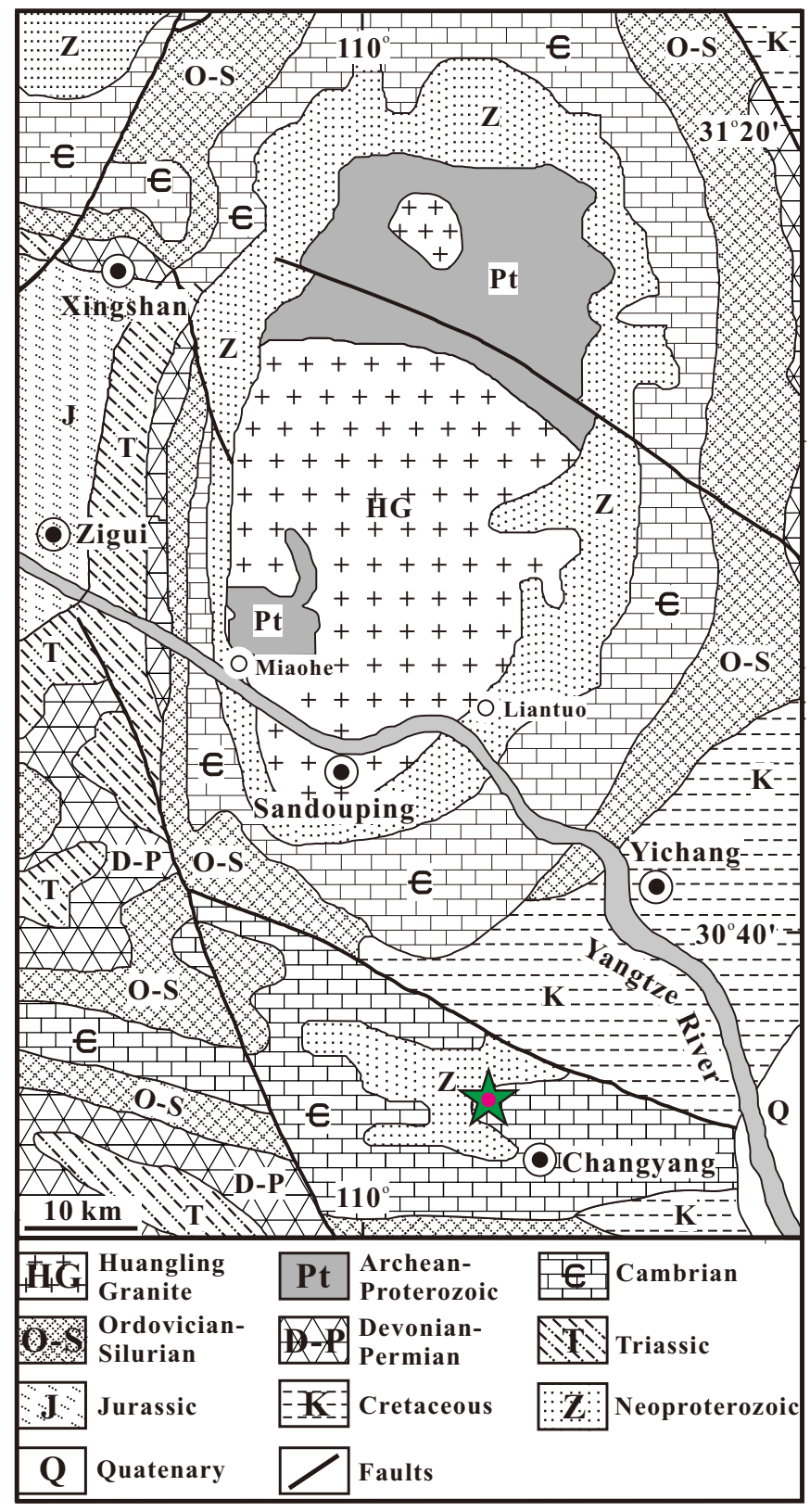

(B)

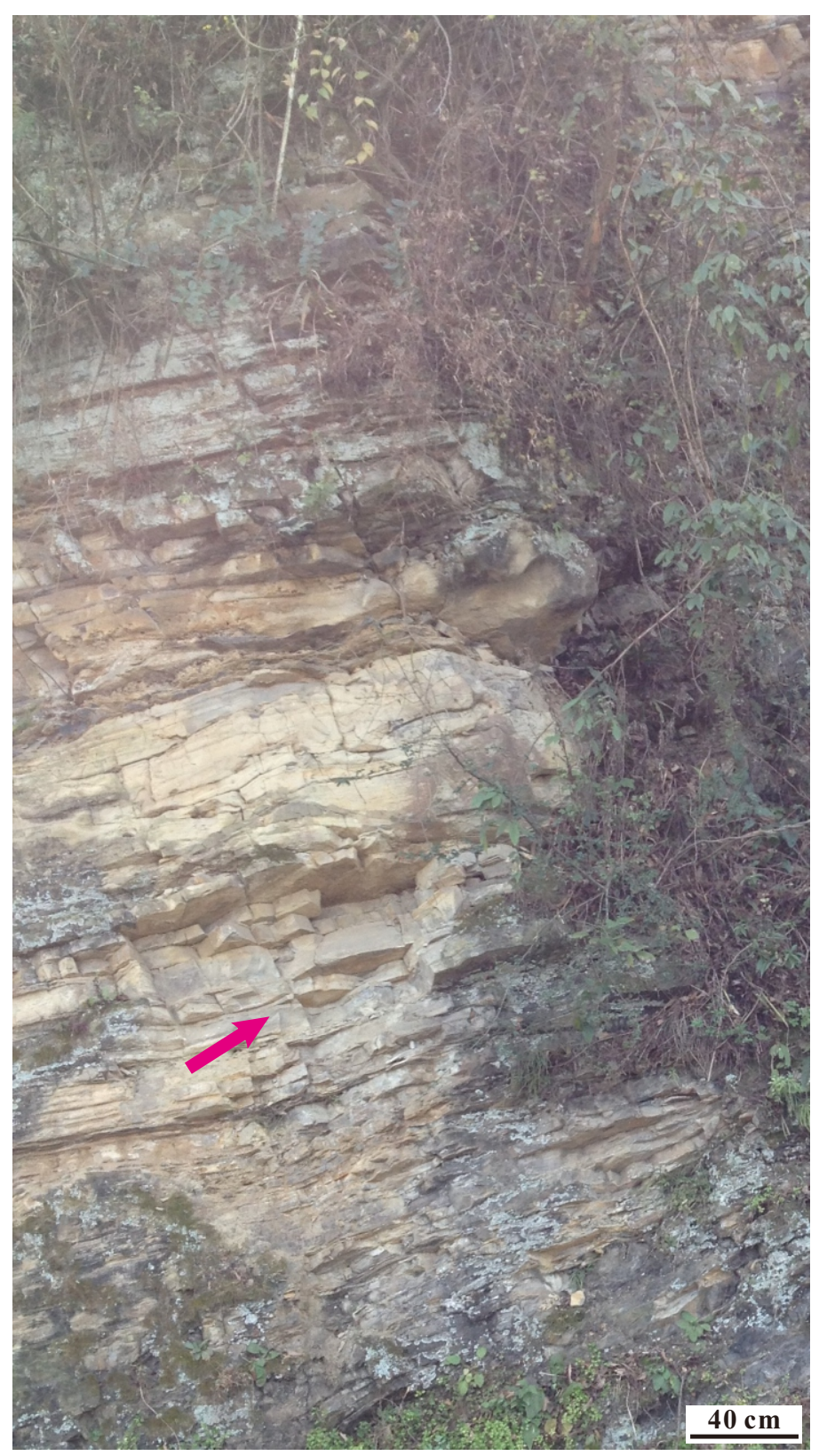




\section{Gao et al. Figure 2}

(A)

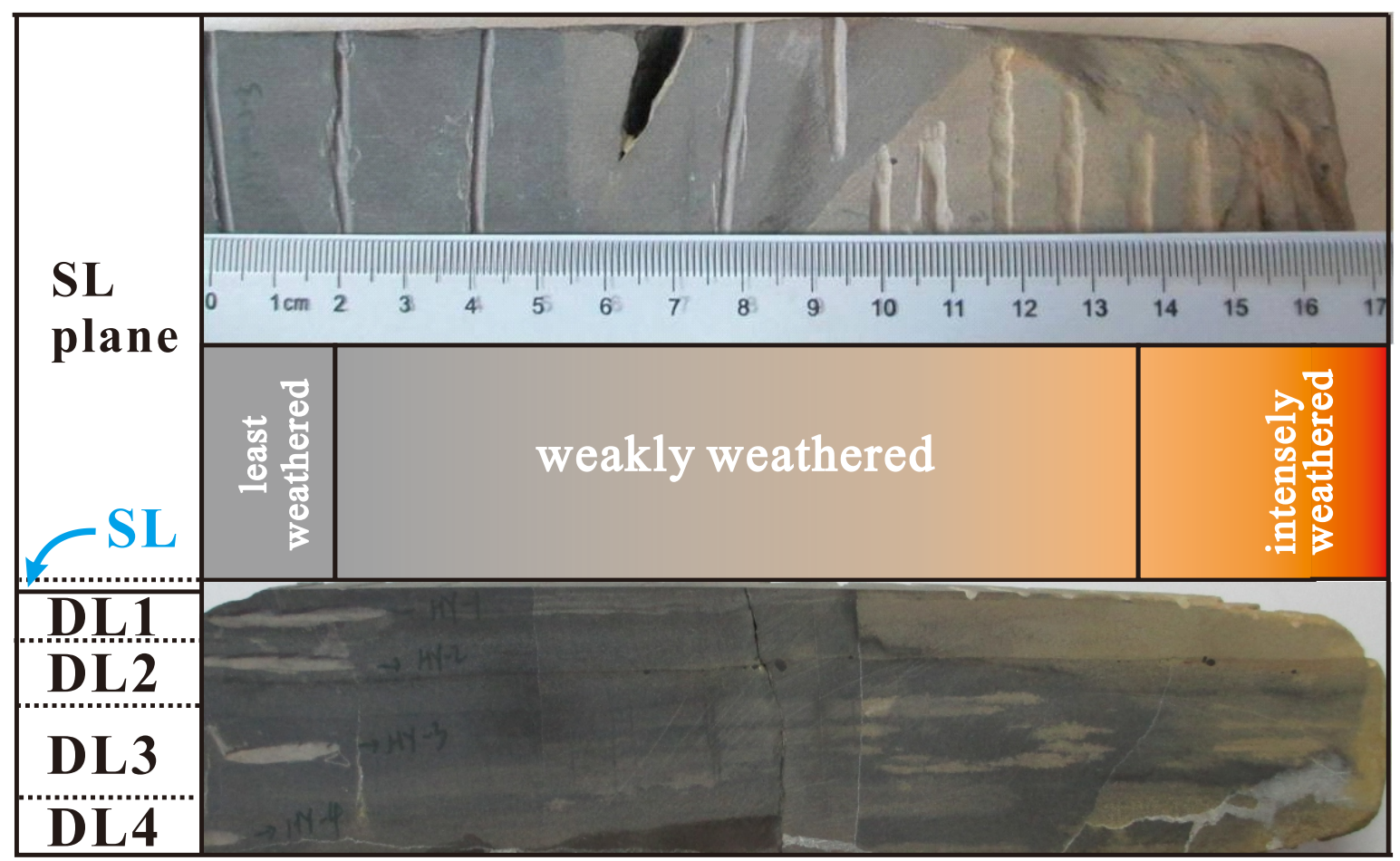

(B)

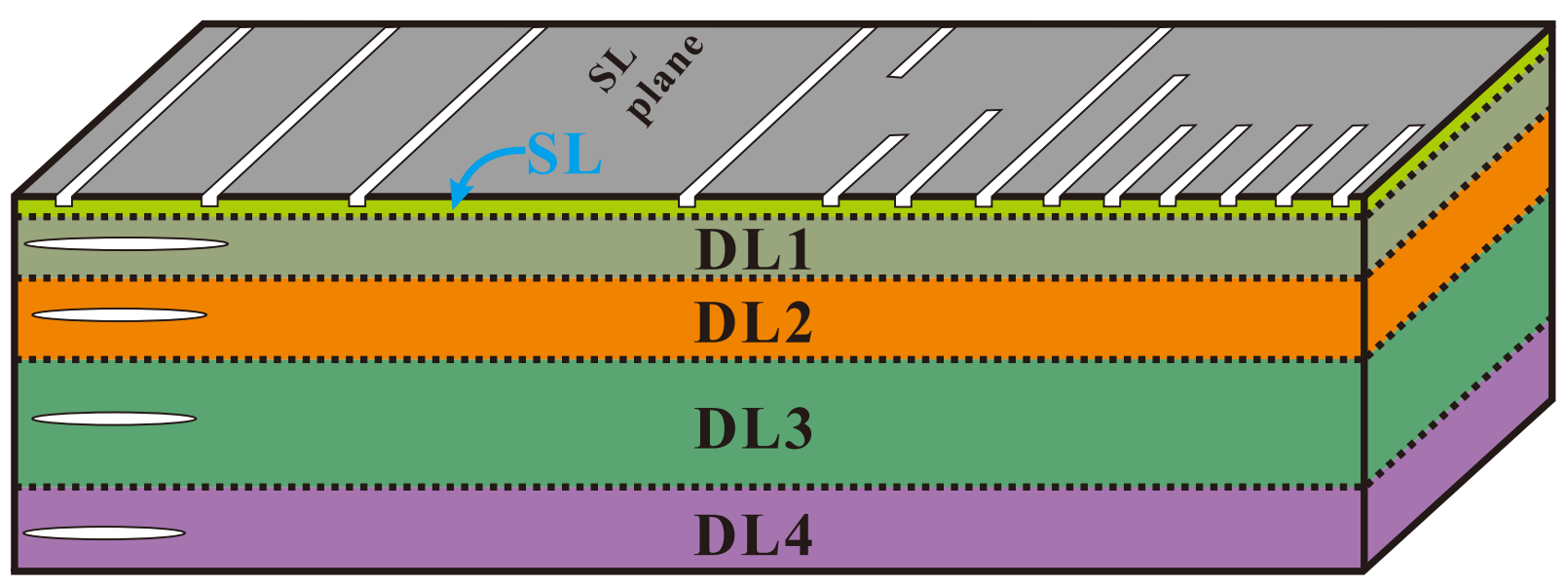




\section{Gao et al. Figure 3}

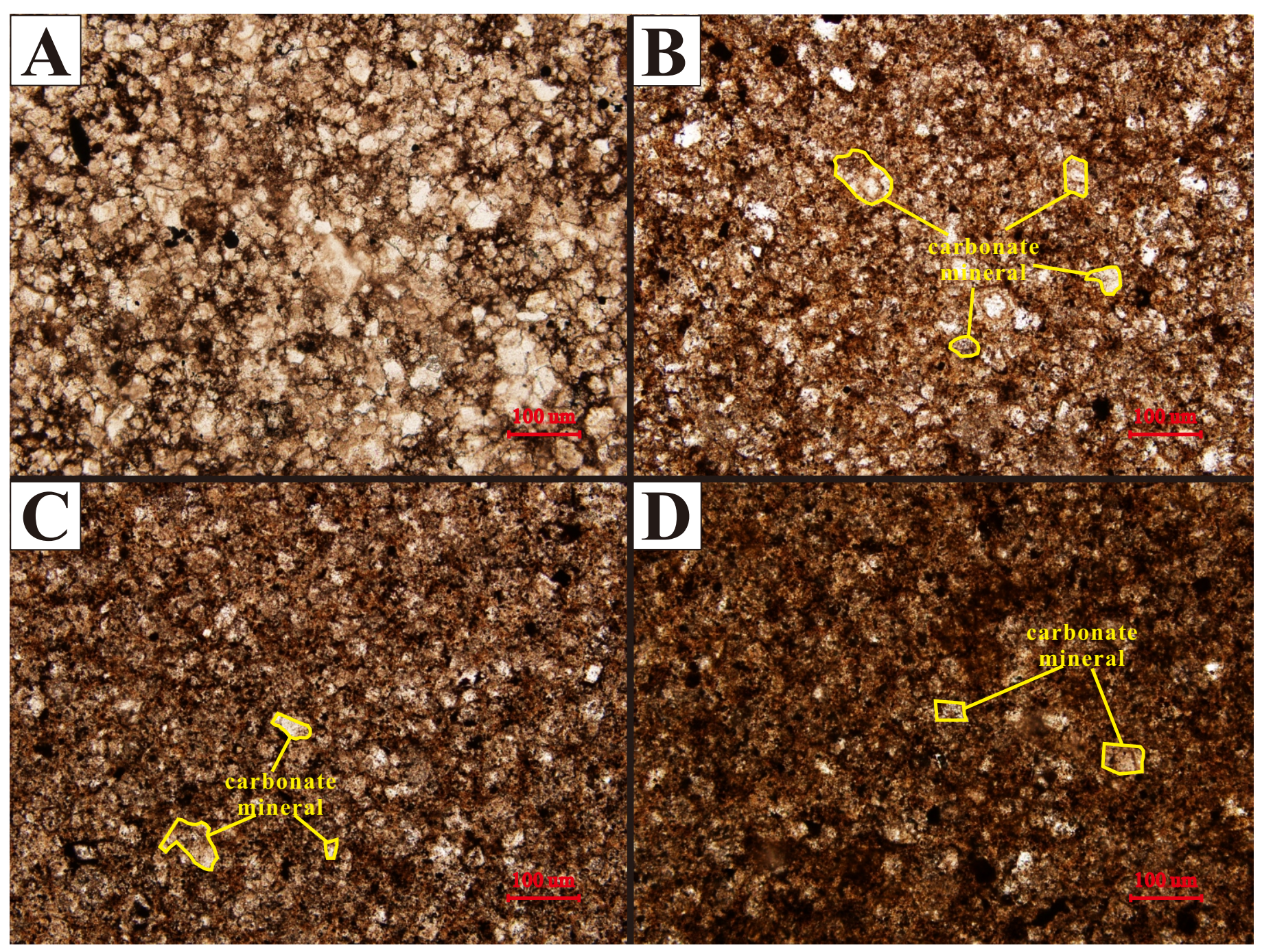


Gao et al. Figure 4

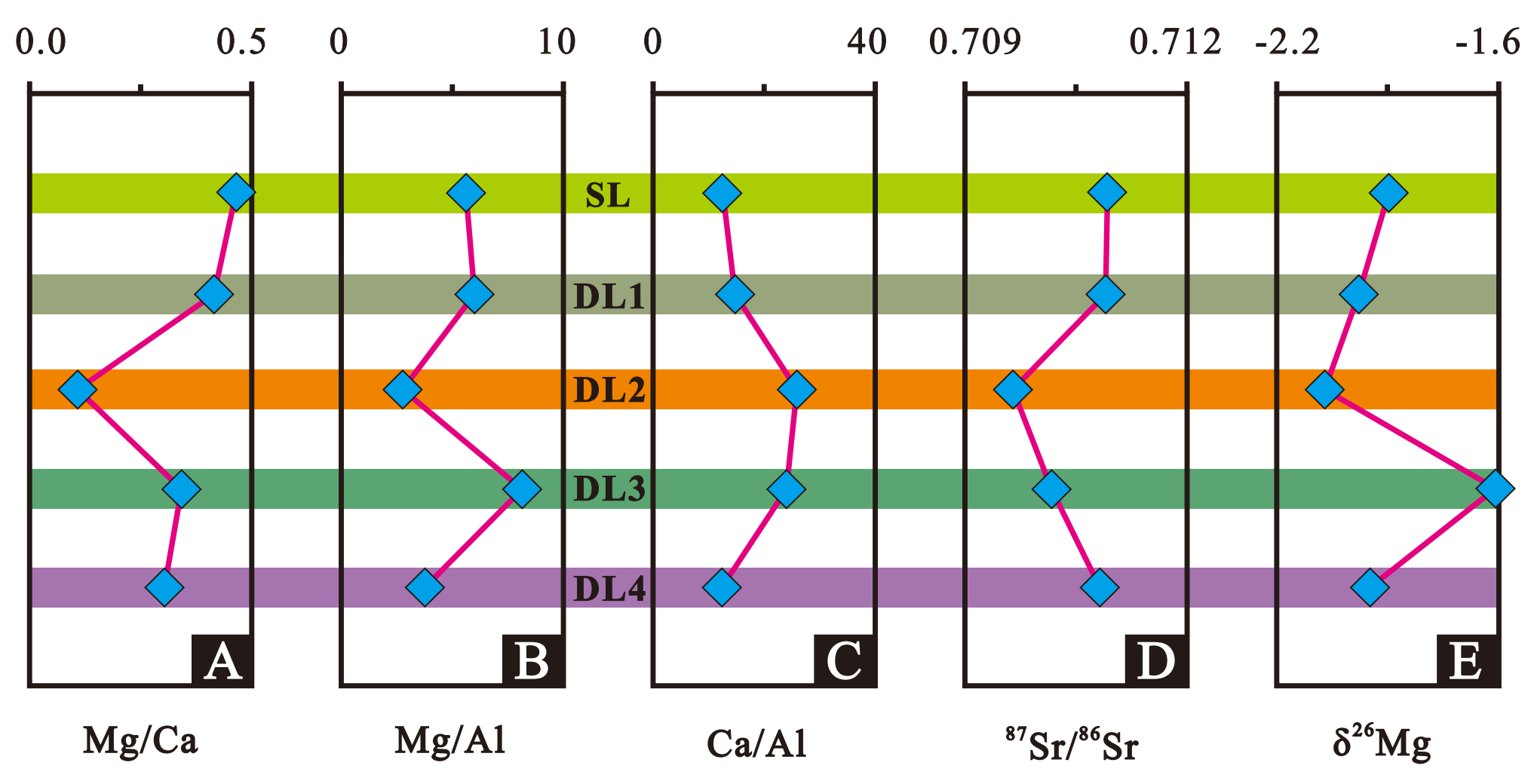




\section{Gao et al. Figure 5}
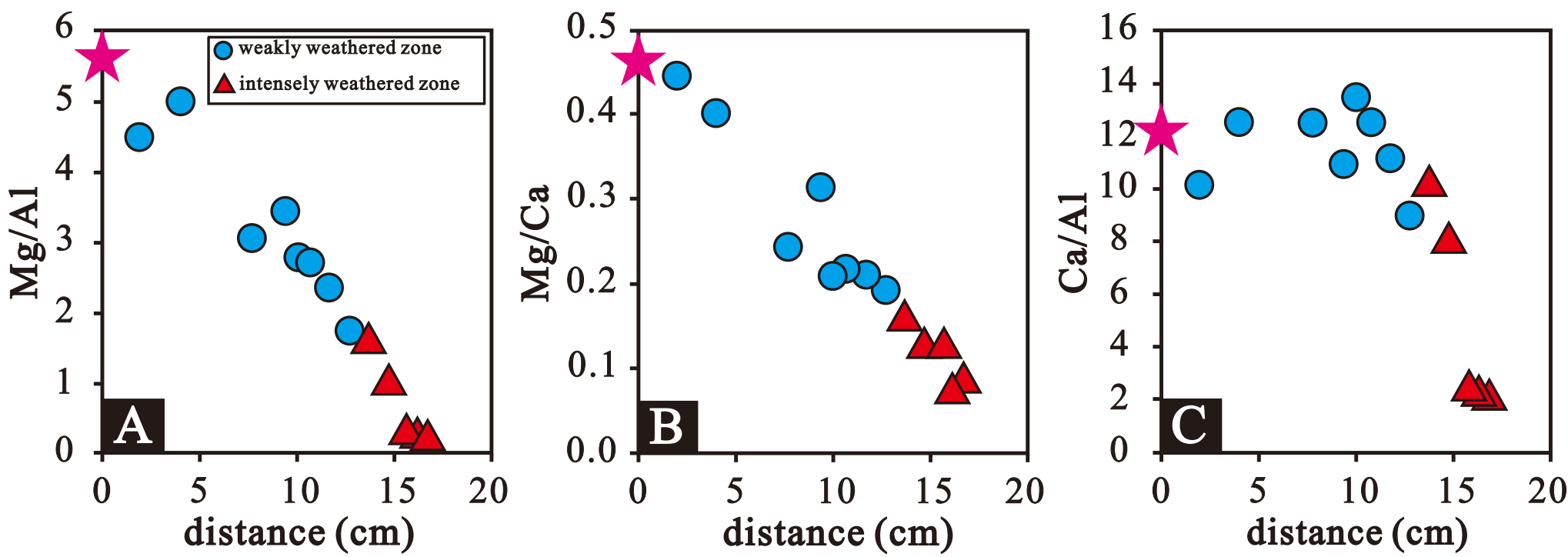
Gao et al. Figure 6
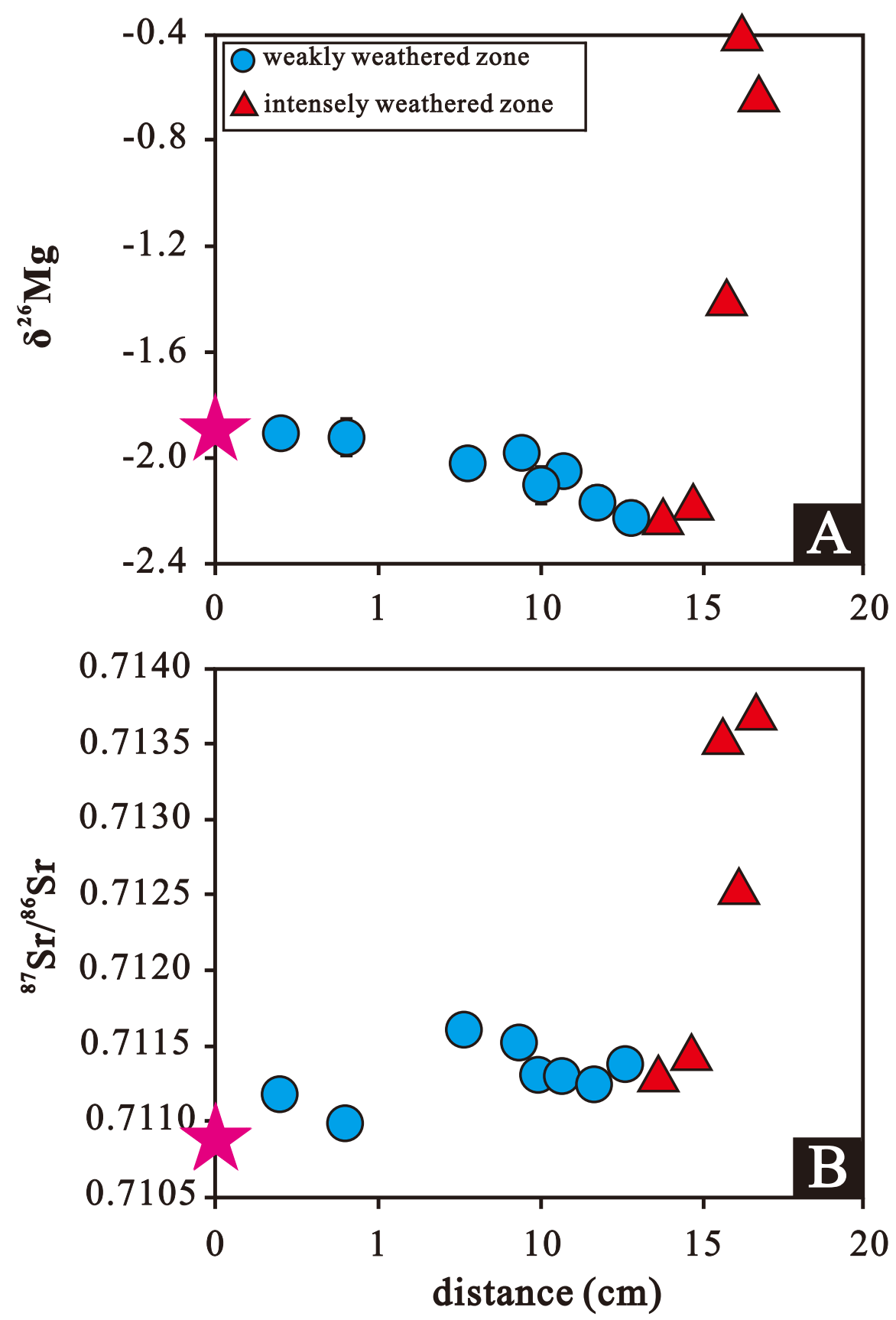
Gao et al. Figure 7

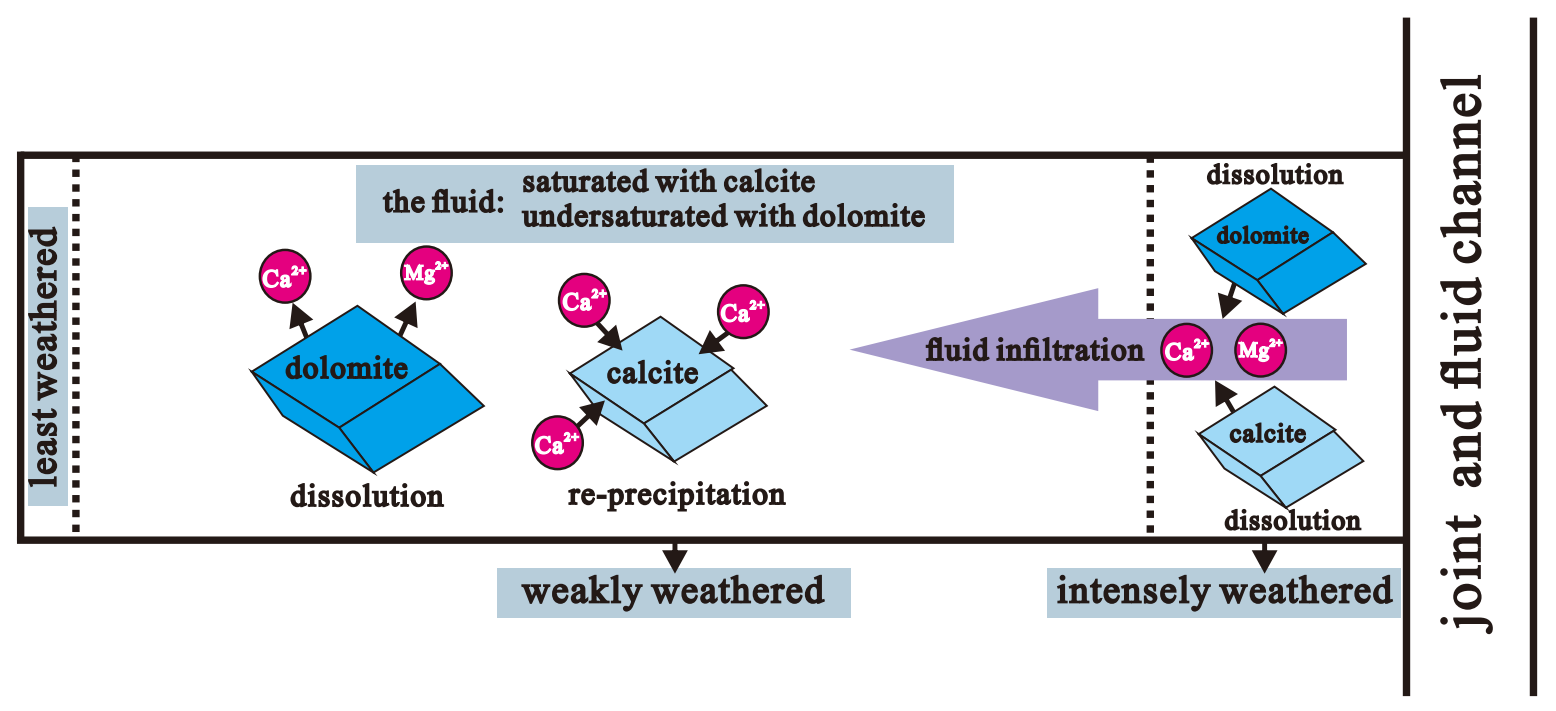


Gao et al. Figure 8
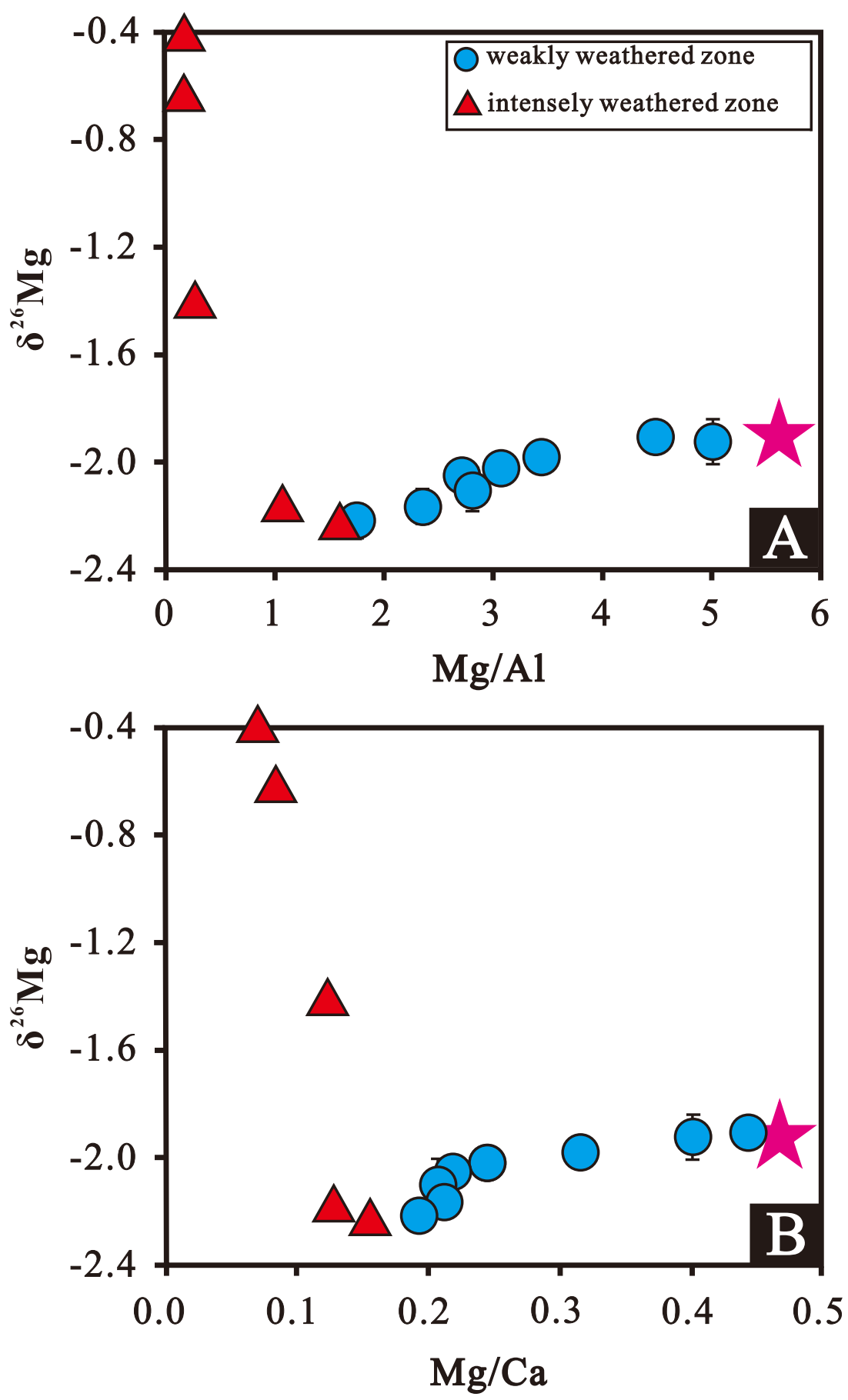


\section{Gao et al. Figure 9}
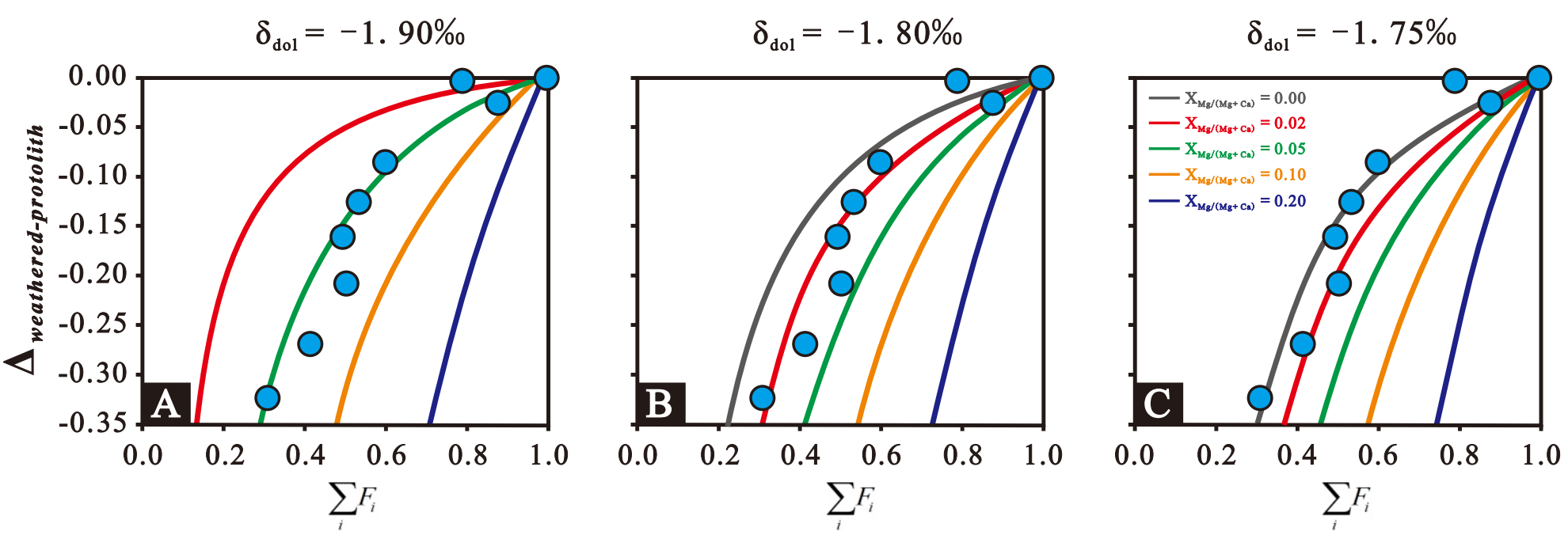